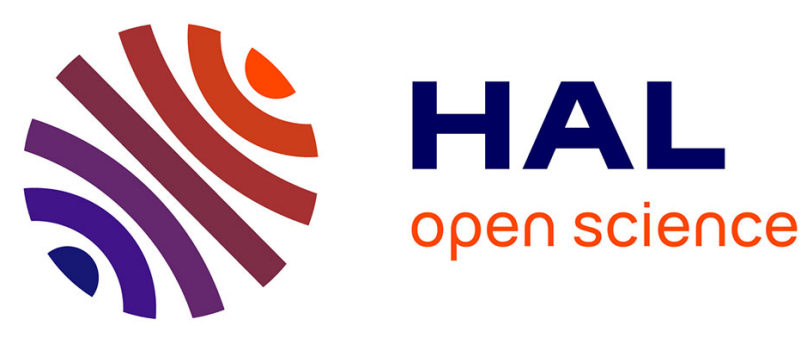

\title{
Diastereoselective deprotonative metalation of chiral ferrocene derived acetals and esters using mixed lithium-cadmium and lithium-zinc combinations
}

Gandrath Dayaker, Aare Sreeshailam, D. Venkata Ramana, Floris Chevallier, Thierry Roisnel, Shinsuke Komagawa, Ryo Takita, Masanobu Uchiyama, Palakodety Radha Krishna, Florence Mongin

\section{To cite this version:}

Gandrath Dayaker, Aare Sreeshailam, D. Venkata Ramana, Floris Chevallier, Thierry Roisnel, et al.. Diastereoselective deprotonative metalation of chiral ferrocene derived acetals and esters using mixed lithium-cadmium and lithium-zinc combinations. Tetrahedron, 2014, 70 (12), pp.2102-2117. 10.1016/j.tet.2014.02.010 . hal-00993136

\section{HAL Id: hal-00993136 https://hal.science/hal-00993136}

Submitted on 20 May 2014

HAL is a multi-disciplinary open access archive for the deposit and dissemination of scientific research documents, whether they are published or not. The documents may come from teaching and research institutions in France or abroad, or from public or private research centers.
L'archive ouverte pluridisciplinaire HAL, est destinée au dépôt et à la diffusion de documents scientifiques de niveau recherche, publiés ou non, émanant des établissements d'enseignement et de recherche français ou étrangers, des laboratoires publics ou privés. 


\title{
Graphical Abstract
}
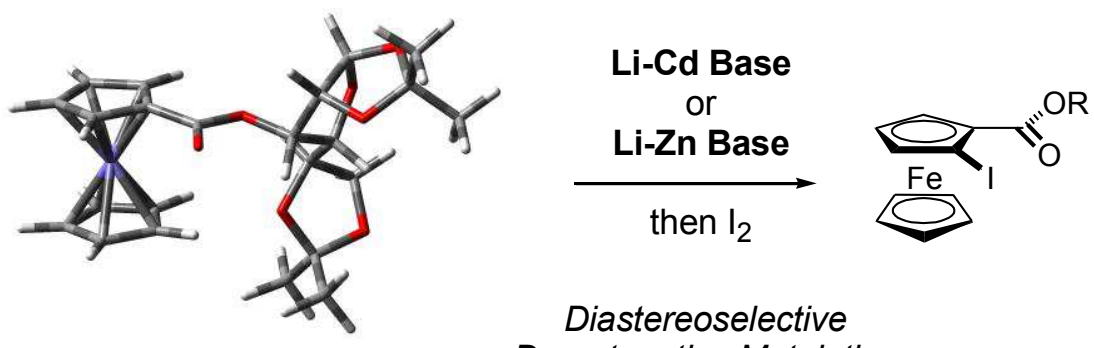

Diastereoselective Deprotonative Metalation

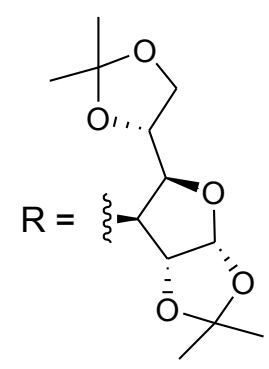

\section{Diastereoselective deprotonative metalation of chiral}

\section{ferrocene derived acetals and esters using mixed lithium-}

\section{cadmium and lithium-zinc combinations}

\author{
Gandrath Dayaker, ${ }^{\mathrm{a}, \mathrm{b}}$, Aare Sreeshailam ${ }^{\mathrm{a}, \mathrm{b}}$, D. Venkata Ramana ${ }^{\mathrm{a}, \mathrm{b}}$, Floris Chevallier ${ }^{\mathrm{a}}$, \\ Thierry Roisnel ${ }^{\mathrm{c}}$, Shinsuke Komagawa ${ }^{\mathrm{d}}$, Ryo Takita ${ }^{\mathrm{d}}$, Masanobu Uchiyama ${ }^{\mathrm{d}, *}$, \\ Palakodety Radha Krishna, ${ }^{b}{ }^{*}$ Florence Mongin ${ }^{a,}$
}

${ }^{a}$ Chimie et Photonique Moléculaires, Institut des Sciences Chimiques de Rennes, UMR 6226, CNRSUniversité de Rennes 1, Bâtiment 10A, Case 1003, Campus de Beaulieu, 35042 Rennes, France

${ }^{\mathrm{b}}$ D-211, Discovery Laboratory, Organic and Biomolecular Chemistry Division, CSIR-Indian Institute of Chemical Technology, Hyderabad-500007, India

${ }^{\mathrm{c}}$ Centre de Diffractométrie X, Institut des Sciences Chimiques de Rennes, UMR 6226, CNRSUniversité de Rennes 1, Bâtiment 10B, Campus de Beaulieu, 35042 Rennes, France

${ }^{\mathrm{d}}$ Graduate School of Pharmaceutical Sciences, The University of Tokyo, 7-3-1 Hongo, Bunkyo-ku, Tokyo, 113-0033, Japan; Advanced Elements Chemistry Research Team, RIKEN Center for Sustainable Resource Science, and Elements Chemistry Laboratory, RIKEN, 2-1 Hirosawa, Wako-shi, Saitama 351-0198, Japan

* Corresponding authors. E-mail addresses: uchiyama@mol.f.u-tokyo.ac.jp (M. Uchiyama), prkgenius@iict.res.in (P. Radha Krishna), florence.mongin@univ-rennes1.fr (F. Mongin).

Keywords: deprotometalation, ferrocene, carbohydrates, lithium, zinc, cadmium 


\begin{abstract}
:
In situ bimetal combinations, and notably those prepared from $\mathrm{MCl}_{2}(\cdot \mathrm{TMEDA})(\mathrm{M}=\mathrm{Zn}, \mathrm{Cd}$; TMEDA $=N, N, N^{\prime}, N^{\prime}$-tetramethylethylenediamine $)$ and $\operatorname{Li}(\mathrm{TMP}) \quad(3$ or 4 equiv, $\mathrm{TMP}=2,2,6,6-$ tetramethylpiperidino), were screened for their ability to diastereoselectively deprotonate ferrocenes bearing a chiral group. The ferrocene carboxylate generated from diacetone-D-glucose afforded the corresponding 2-iodo derivative in $74 \%$ yield with $90 \%$ de ( $S_{\mathrm{P}}$ diastereoisomer) using the base generated from $\mathrm{CdCl}_{2}$ and $\mathrm{Li}(\mathrm{TMP})$ (3 equiv), and in $85 \%$ yield with $91 \%$ de $\left(S_{\mathrm{P}}\right.$ diastereoisomer) through a double asymmetric induction using a chiral lithium-zinc base generated from $\mathrm{ZnCl}_{2} \cdot \mathrm{TMEDA}$ and lithium $(R)$-bis(1-phenylethyl)amide (4 equiv). In contrast, using a combination prepared from $\mathrm{ZnCl}_{2}$ and $\mathrm{Li}(\mathrm{TMP})$ (4 equiv) with the ferrocene carboxylate obtained from 6-(tertbutoxycarbonylamino)-6-deoxy-3-O-methyl-1,2-O-isopropylidene- $\alpha$-D-glucofuranose led to the $R_{\mathrm{P}^{-}}$ iodo derivative in 57\% yield after separation. Suzuki coupling was performed satisfactorily on the isolated $S_{\mathrm{P}}$ and $R_{\mathrm{P}}$ diastereoisomer iodoesters.
\end{abstract}

\title{
1. Introduction
}

Metalation of aromatic compounds is traditionally performed using lithium bases in the presence of Lewis bases that simplify their aggregation state (e.g. tetrahydrofuran (THF) as solvent or $N, N, N^{\prime}, N^{\prime}-$ tetramethylethylenediamine (TMEDA) as additive). ${ }^{1}$ Nevertheless, polar carbon-lithium bonds are hardly compatible with substrates bearing reactive functions (esters, nitriles...) and $\pi$-deficient heterocycles. As a consequence, when these sensitive aromatic compounds are submitted to conventional lithium bases in deprotonation reactions, very low temperatures and/or the presence of an in situ electrophile are required. ${ }^{1}$ By changing lithium with magnesium, the chemoselectivity of the reactions can be improved, but to the detriment of the efficiency since a large excess of base has to be used due to its reduced reactivity. ${ }^{2}$

Activation of lithium bases by metal additives in order to obtain more efficient and/or more chemoselective deprotonation reactions is a challenging field, and many $\left[(R)_{n}\left(R^{\prime}\right)_{n^{\prime}} M L i\right]-t y p e$ 
superbases $\left(\mathrm{M}=\right.$ metal; $\mathrm{R}, \mathrm{R}^{\prime}=$ alkyl, amino, chloro...) have already been reported. ${ }^{3}$ Mixtures of organolithiums and $\mathrm{M}$ alkali metal alkoxides were the first to be developed; well-known examples are LIC-KOR $(\mathrm{LIC}=\text { butyllithium, } \mathrm{KOR}=\text { potassium } \text { tert-butoxide })^{4}$ and BuLi-Li(DMAE) $(\mathrm{DMAE}=2-$ dimethylaminoethoxide). ${ }^{5}$ Later, the synergy exhibited by merging lithium compounds with softer nonalkali derivatives significantly pushed the limits of aromatic deprotonative metalation to new heights. Indeed, $\left[(\mathrm{R})_{\mathrm{n}}\left(\mathrm{R}^{\prime}\right)_{\mathrm{n}^{\prime}} \mathrm{MLi}\right]$-type compounds with $\mathrm{M}$ different from an alkali metal displayed a large panel of reactivities, depending on both the metal $\mathrm{M}$ and its ligands; in particular, TMP-containing combinations (TMP $=2,2,6,6$-tetramethylpiperidino) were identified as useful bases to perform the aromatic functionalization of a large range of substrates. $^{6}$

Within this framework, we developed pairs of metal amides which complement each other in deproto-metalation reactions. In particular, the TMP-based lithium-zinc ${ }^{7}$ and lithium-cadmium mixtures, ${ }^{8}$ respectively prepared from $\mathrm{ZnCl}_{2} \cdot \mathrm{TMEDA}$ and $\mathrm{CdCl}_{2} \cdot \mathrm{TMEDA}$, and Li(TMP) (3 equiv), were identified as suitable reagents to chemoselectively functionalize a variety of aromatics. Due to the importance of ferrocenes for applications ranging from catalysis ${ }^{9}$ to materials science $^{10}$ and bioorganometallic chemistry, ${ }^{11}$ such base combinations were also successfully applied to the functionalization of acetal- and ester-substituted derivatives through room temperature metalationiodination sequences. $^{7 \mathrm{~d}, 12}$

The presence of a heteroatom-containing substituent on ferrocene usually directs lithiation to the adjacent position, affording 1,2-unsymmetrical derivatives upon quenching with electrophiles. Suitable chiral groups were early identified in order to control the absolute planar chiral configuration in the course of such reactions. ${ }^{13}$ We recently communicated diastereoselective deproto-metalation reactions

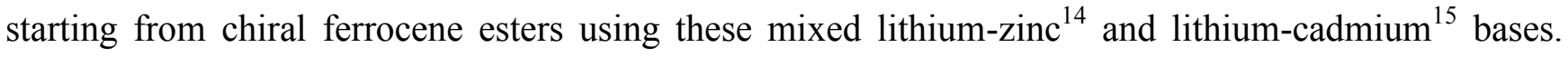
Herein, the details of our investigations on sugar-based ferrocene acetals and esters are recorded.

\section{Results and Discussion}


Chiral acetals being described as suitable functions to induce diastereoselective lithiation of the corresponding ferrocenes, ${ }^{16}$ we first considered such substrates to evaluate our basic combinations. Accordingly, the synthesis of the chiral ferrocene acetals derived from the commercially available 1,2$O$-isopropylidene-3- $O$-methyl- $\alpha$-D-glucofuranose (1a), 1,2:5,6-di- $O$-isopropylidene-D-mannitol (1b), and 1,2-O-isopropylidene- $\alpha$-D-xylofuranose (1c) diols was undertaken first. The reactions were carried out with ferrocene dimethylacetal in chloroform, using $p$-toluenesulfonic acid as catalyst. ${ }^{16 a}$ Whereas the transacetalization using the diols $\mathbf{1 a}, \mathbf{b}$ gave diastereoisomeric mixtures, a single compound $\mathbf{2 c}$ was obtained using the diol 1c, and was characterized unambiguously by X-ray diffraction (Scheme 1).

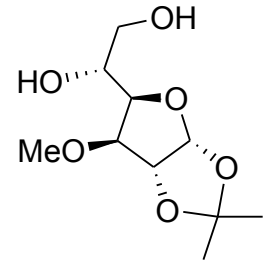

$1 \mathrm{a}$

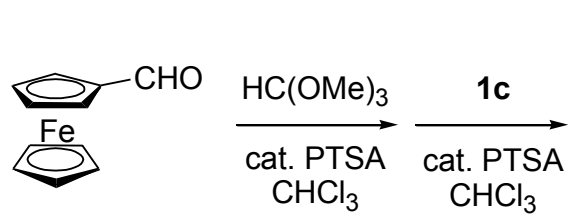

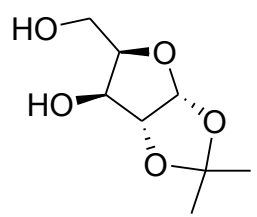

1c

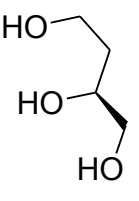

1d

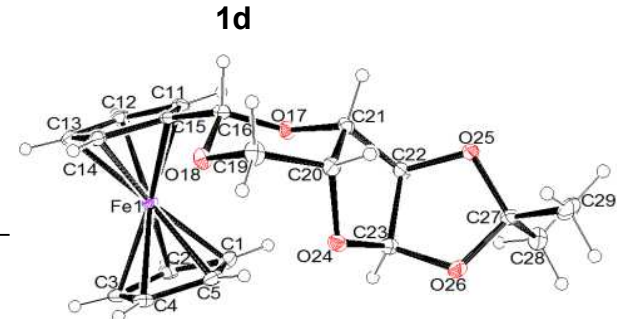

Scheme 1. Polyols 1a-d, synthesis of the chiral ferrocene acetal $2 \mathbf{c}$ and ORTEP diagram (30\% probability) of the acetal 2c.

Different reagents were employed in the deprotonation of 2c, amongst all (i) the all TMP lithiumcadmium combination already identified as being able to perform chemoselective reactions efficiently, ${ }^{8}$ (ii) other organolithiums (BuLi, BuLi $\cdot$ TMEDA, ${ }^{s} \mathrm{BuLi},{ }^{t} \mathrm{BuLi}$ in THF), and (iii) ${ }^{t} \mathrm{BuLi} \cdot{ }^{t} \mathrm{BuOK}$ reported as capable of deprotonating bare ferrocene. ${ }^{17}$ Unfortunately, whatever the conditions used with the lithium-cadmium base (THF, room temperature or pentane, reflux), with the organolithium compounds (THF, $-10{ }^{\circ} \mathrm{C}$ to room temperature), and with ${ }^{t} \mathrm{BuLi} \cdot{ }^{t} \mathrm{BuOK}$ (THF, -75 to $-15{ }^{\circ} \mathrm{C}$ ), only starting ferrocene, ferrocenecarboxaldehyde (deprotection of the acetal function), and its corresponding addition derivatives were observed after the workup with no deprotonation occurring at all. ${ }^{18}$ 
Undeterred by these results, we considered the involvement of the Kagan's ferrocene acetal ${ }^{16 a, 16 c, 16 s}$ 2d (derived from the commercially available triol 1d) in the deproto-metalation using lithium-zinc and lithium-cadmium combinations (Table 1). Using the base in situ prepared in $\mathrm{THF}$ at $0{ }^{\circ} \mathrm{C}(15 \mathrm{~min})$ from $\mathrm{ZnCl}_{2} \cdot \mathrm{TMEDA}$ ( 1 equiv) and $\mathrm{Li}(\mathrm{TMP})$ (3 equiv) led, after $2 \mathrm{~h}$ at room temperature and subsequent interception with iodine, to the iodide $\mathbf{3 d}$ and the diiodide $\mathbf{4 d}$ in 75 and $15 \%$ yield, respectively. Analysis of the iodide $3 \mathbf{d}$ by ${ }^{1} \mathrm{H}$ NMR showed a $69 \%$ de, and comparison with previously reported spectral ${ }^{13} \mathrm{C}$ NMR data ${ }^{16 r}$ allowed the main diastereoisomer to be identified as $\boldsymbol{S}_{\mathbf{P}}$ (entry 1). The base employed being a 1:1 mixture of $\mathrm{Zn}(\mathrm{TMP})_{2}$ and $\mathrm{Li}(\mathrm{TMP}),{ }^{7 \mathrm{i}}$ the sequential addition to the substrate $\mathbf{2 d}$ of a THF solution of $\mathrm{ZnCl}_{2} \cdot \mathrm{TMEDA}$ (1 equiv) and $\mathrm{Li}(\mathrm{TMP})$ (2 equiv) and, 30 min later, a THF solution of $\operatorname{Li}(\mathrm{TMP})\left(1\right.$ or 2 equiv) at $-30{ }^{\circ} \mathrm{C}$ was attempted. After $2 \mathrm{~h}$ stirring at this temperature and iodolysis, no diiodide was observed but a mixture of the iodide $\mathbf{3 d}$ (37 or $45 \%$ yield, respectively) with starting material $2 \mathbf{d}$ (35 or 27\%). Under these conditions, the de, still in favor of the $S_{\mathrm{P}}$ diastereoisomer, was slightly improved to reach 76 or $79 \%$, respectively (entries 2 and 3 ).

Table 1. Metalation of the Kagan's ferrocene acetal 2d using lithium-zinc and lithium-cadmium combinations followed by trapping with $\mathrm{I}_{2}$.

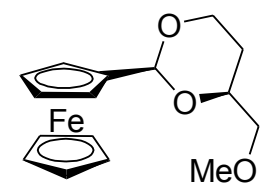

2d

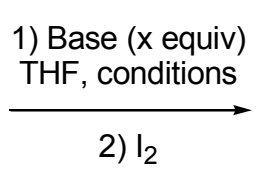

2) $\mathrm{I}_{2}$

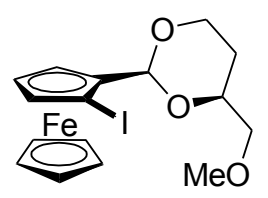

3d

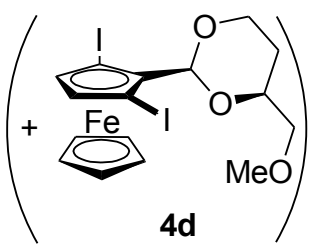

\begin{tabular}{|c|c|c|c|c|c|}
\hline Entry & Base ( $\mathrm{x}$ equiv) & Conditions & $\begin{array}{l}\text { Yield of } \\
\text { 3d }(\%)\end{array}$ & $\begin{array}{l}\text { Yield of } \\
\mathbf{4 d}(\%)\end{array}$ & $\operatorname{de}(\%)^{\mathrm{a}}$ \\
\hline 1 & $\mathrm{ZnCl}_{2} \cdot \mathrm{TMEDA}(1)+\mathrm{Li}(\mathrm{TMP})(3)$ & $\mathrm{rt}, 2 \mathrm{~h}$ & 75 & 15 & $69\left(S_{\mathrm{P}}\right)^{\mathrm{b}}$ \\
\hline$\overline{2}$ & $\begin{array}{l}\mathrm{ZnCl}_{2} \cdot \mathrm{TMEDA}_{\text {(1) }+\mathrm{Li}(\mathrm{TMP})(2)} \\
\text { and, } 30 \text { min later, } \mathrm{Li}(\mathrm{TMP})(1)\end{array}$ & $-30{ }^{\circ} \mathrm{C}, 2 \mathrm{~h}$ & $37^{\mathrm{c}, \mathrm{d}}$ & 0 & $76\left(S_{\mathrm{P}}\right)^{\mathrm{b}}$ \\
\hline$\overline{3}$ & $\begin{array}{l}\mathrm{ZnCl}_{2} \cdot \mathrm{TMEDA}(1)+\mathrm{Li}(\mathrm{TMP})(2) \\
\text { and, } 30 \text { min later, Li(TMP) (2) }\end{array}$ & $-30^{\circ} \mathrm{C}, 2 \mathrm{~h}$ & $45^{\mathrm{e}, \mathrm{d}}$ & 0 & $79\left(S_{\mathrm{P}}\right)^{\mathrm{b}}$ \\
\hline$\overline{4}$ & $\mathrm{CdCl}_{2} \cdot \mathrm{TMEDA}(1)+\mathrm{Li}(\mathrm{TMP})(3)$ & $\mathrm{rt}, 2 \mathrm{~h}$ & 0 & 79 & \\
\hline 5 & $\mathrm{CdCl}_{2} \cdot \mathrm{TMEDA}(0.5)+\mathrm{Li}(\mathrm{TMP})(1.5)$ & $\mathrm{rt}, 2 \mathrm{~h}$ & $41^{\mathrm{t}, \mathrm{d}}$ & 0 & $71\left(S_{\mathrm{P}}\right)^{6}$ \\
\hline
\end{tabular}

${ }^{\text {a }}$ Determined from the integration of the ${ }^{1} \mathrm{H}$ NMR spectrum of the crude mixture (signals at 5.41 and $5.38 \mathrm{ppm}$ in $\mathrm{CDCl}_{3}$ or at 5.45 and $5.42 \mathrm{ppm}$ in $\mathrm{C}_{6} \mathrm{D}_{6}$ ) for the $S_{\mathrm{P}}$ and $R_{\mathrm{P}}$ diastereoisomer, respectively).

${ }^{\mathrm{b}}$ The attribution of the configuration was made on the basis of previously reported data. ${ }^{16 \mathrm{r}}$

c $35 \%$ of $2 \mathrm{~d}$ was recovered.

${ }^{\mathrm{d}}$ Estimated yield, due to the presence of starting material.

e $27 \%$ of $2 \mathrm{~d}$ was recovered.

f $53 \%$ of $2 \mathrm{~d}$ was recovered. 
Using the corresponding lithium-cadmium base, prepared from $\mathrm{CdCl}_{2} \cdot \mathrm{TMEDA}(1$ equiv) and Li(TMP) (3 equiv), the diiodide $4 \mathbf{d}$ proved to be the only product formed (entry 4 ). Reducing the amount of base furnished the monoiodide $\mathbf{3 d}$, but in moderate yield and de similar to that obtained using the lithium-zinc base (entry 5).

Encouraged by these preliminary results, we decided to consider the use of chiral groups with which monometal lithium bases are not compatible. A literature survey showed that ferrocene chiral esters have never been used for this purpose. ${ }^{13 \mathrm{~b}, 13 \mathrm{e}}$ In a previous paper, we reported the possible deprotonative metalation of ferrocene esters using the all TMP lithium-zinc and lithium-cadmium combinations. ${ }^{7 \mathrm{~d}}$ Inspired, we turned our attention to the variety of chiral ferrocene esters 6a-n, prepared from ferrocenecarboxylic acid and the alcohols 5a-n (Scheme 2) under classical conditions, ${ }^{19}$ in order to attempt their diastereoselective deproto-metalation.
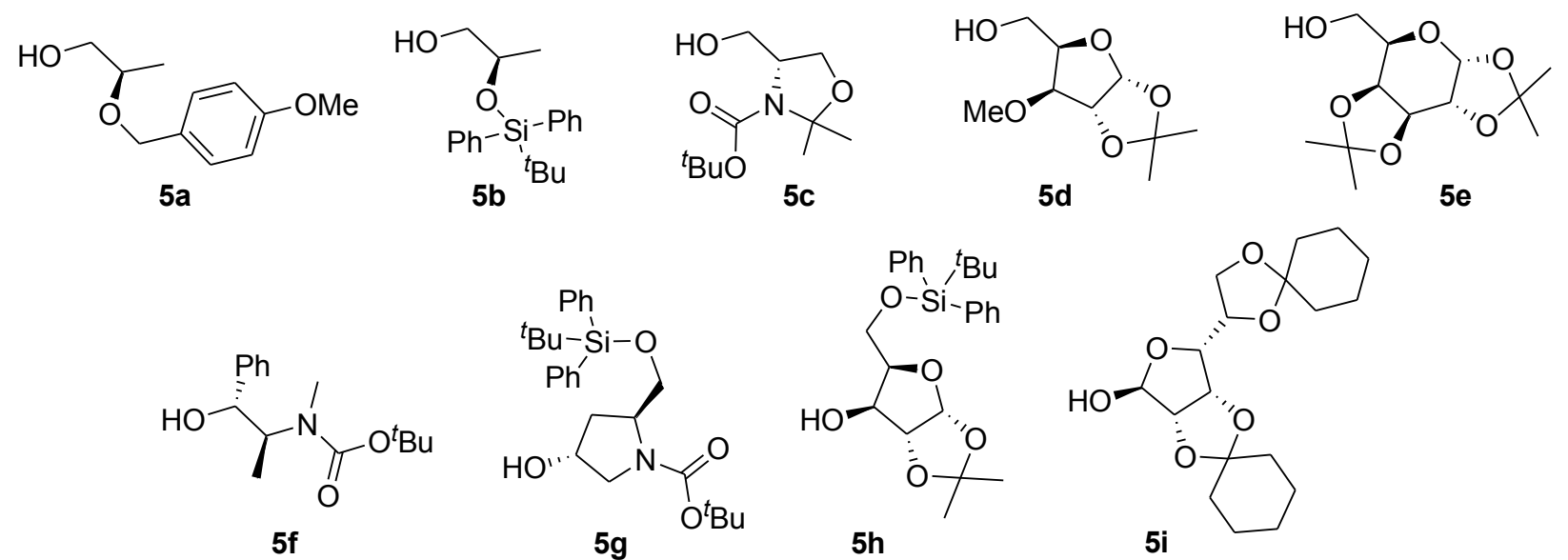

$5 d$

$5 e$
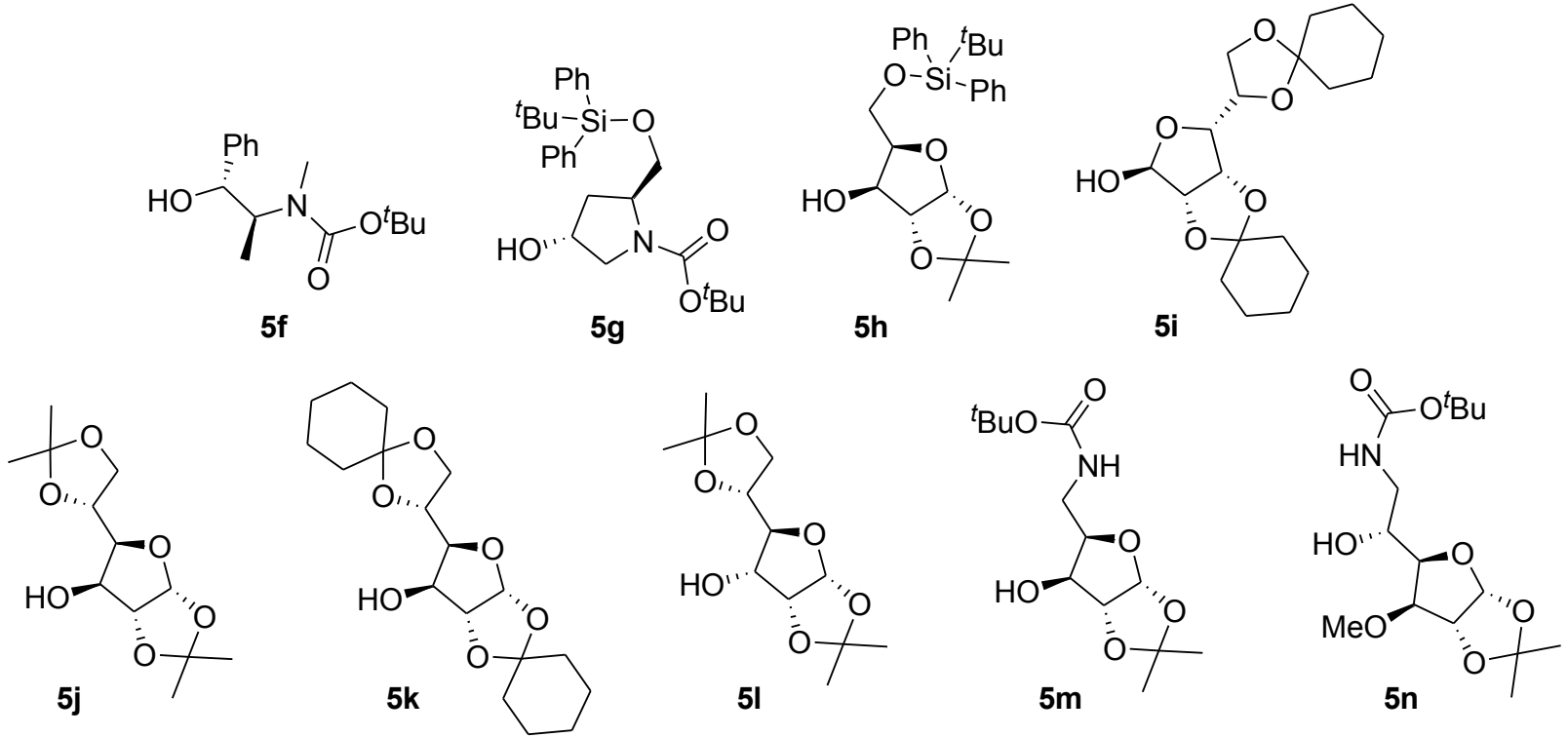

Scheme 2. Chiral alcohols 5 used to prepare the ferrocene esters.

The metalation of PMB- and TBDPS-protected (R)-2-hydroxypropyl ferrocenecarboxylate 6a,b was first attempted using the lithium-cadmium base prepared in situ from $\mathrm{CdCl}_{2} \cdot \mathrm{TMEDA}$ (x equiv) and 
Li(TMP) (3x equiv) in THF at room temperature (Table 2). With $x=1$, the diiodides $\mathbf{8 a}, \mathbf{b}$ were formed in low to moderate yields (29 and 68\%, respectively, entries 1 and 2). However, reducing the amount of base $(x=0.5)$ resulted in the formation of the monoiodides $7 \mathbf{a}, \mathbf{b}$ as major products (entries 3 and 4 ). Subsequent reduction to 2-iodoferrocenemethanol (9) using DIBAL-H, ${ }^{20}$ and analysis by HPLC using a chiral stationary phase (AS-H) showed that the metalation was not sufficiently diastereoselective.

Table 2. Metalation of PMB- and TBDPS-protected $(R)$-2-hydroxypropyl ferrocenecarboxylates 6a,b using the all TMP lithium-cadmium base followed by trapping with $\mathrm{I}_{2}$.

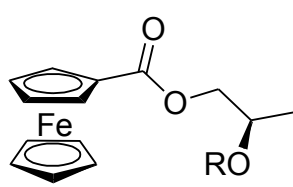

$6 a, b$

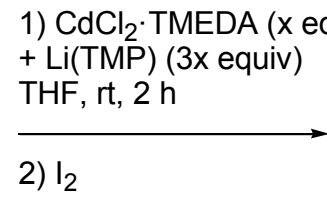

2) $I_{2}$

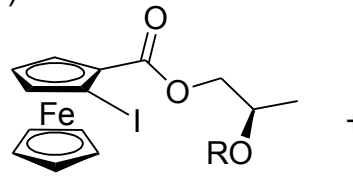

$7 a, b$

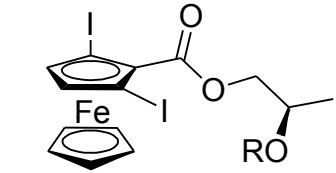

$8 \mathrm{a}, \mathrm{b}$

\begin{tabular}{|c|c|c|c|c|c|c|}
\hline \multirow[b]{2}{*}{ Entry } & \multirow[b]{2}{*}{ Substrate } & & & & \multicolumn{2}{|c|}{$\begin{array}{l}\text { 1) DIBAL-H } \\
\text { THF, } 0^{\circ} \mathrm{C}, 1 \mathrm{~h} \\
\text { 2) Hydrolysis }\end{array}$} \\
\hline & & $\mathrm{R}$ & $\mathrm{x}$ & 7, Yield $(\%)$ & 8, Yield $(\%)$ & Yield $(\%)$ for 9 , ee $(\%)^{a}$ \\
\hline 1 & $6 a$ & PMB & 1 & $7 a, 35$ & $8 a, 29$ & $\mathrm{~b}$ \\
\hline 2 & 6b & TBDPS & 1 & $7 \mathbf{b}, 7$ & $\mathbf{8 b}, 68$ & $b$ \\
\hline$\overline{3}$ & $6 a$ & PMB & 0.5 & $7 \mathbf{a}, 76$ & $8 \mathbf{a}, 7$ & $94,7\left(S_{\mathrm{P}}\right)^{\mathrm{c}}$ \\
\hline 4 & $6 \mathbf{b}$ & TBDPS & 0.5 & $7 b, 54$ & $8 b, 5$ & $98,1\left(S_{\mathrm{P}}\right)^{\mathrm{c}}$ \\
\hline
\end{tabular}

${ }^{a}$ Determined by HPLC analysis on a chiral stationary phase (AS-H column, eluent: 9:1 hexane-isopropanol, $1 \mathrm{~mL} / \mathrm{min}, \lambda=252 \mathrm{~nm}$ ).

${ }^{\mathrm{b}}$ Reduction not performed.

${ }^{c}$ The attribution of the configuration was made on the basis of previously reported data. ${ }^{21}$

Next, another set of chiral ferrocene esters $6 \mathbf{c}-\mathbf{e}$ were taken up for study, prepared from $(R)-N-($ tertbutoxycarbonyl)-4-(hydroxymethyl)-2,2-dimethyloxazolidine (5c), 1,2-O-isopropylidene-3-O-methyl- $\alpha$ D-xylofuranose (5d) and 1,2:3,4-di- $O$-isopropylidene- $\alpha$-D-galactopyranose (5e) as primary alcohols, and ferrocenecarboxylic acid under the earlier mentioned conditions. These esters were converted to the corresponding iodo derivatives 7c-e (Scheme 3, Table 3). While the metalation of 6c proved difficult, giving only a low yield in the presence of 1 equiv of the lithium-cadmium base (entry 1), that of $\mathbf{6 d , e}$ proceeded efficiently using 0.5 equiv of base (entries 2 and 3). As previously observed for $\mathbf{6 a}, \mathbf{b}$, even 
herein low diastereoselectivities were obtained in favor of the $R_{\mathrm{P}}$ diastereoisomer when $5 \mathrm{c}$ was the chiral alcohol used, and in the favor of the $S_{\mathrm{P}}$ diastereoisomer when $\mathbf{5 d , e}$ were the chiral alcohols.

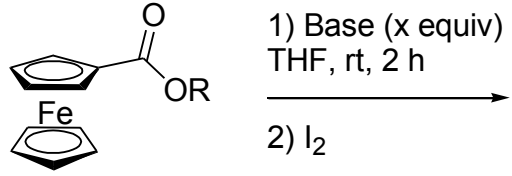

6

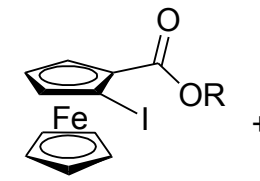

7

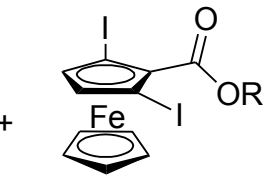

8

1) DIBAL-H THF, $0{ }^{\circ} \mathrm{C}, 1 \mathrm{~h}$

2) Hydrolysis

Scheme 3. Metalation of chiral ferrocenecarboxylates $6 c-i$ using lithium-cadmium or lithium-zinc combination followed by trapping with $\mathrm{I}_{2}$.

Table 3. Metalation of chiral ferrocenecarboxylates 6c-e using the base in situ prepared from $\mathrm{CdCl}_{2} \cdot$ TMEDA (x equiv) and $\mathrm{Li}(\mathrm{TMP})$ (3x equiv) followed by trapping with $\mathrm{I}_{2}$.

\begin{tabular}{|c|c|c|c|c|c|}
\hline Entry & Substrate, R & $\mathrm{x}$ & 7, Yield (\%) & $\mathbf{8}$, Yield $(\%)$ & Yield $(\%)$ for 9 , ee $(\%)^{\mathrm{a}}$ \\
\hline$\overline{1}$ & 6c & 1 & $7 c, 18^{b}$ & 8c, 0 & $98,14\left(R_{\mathrm{P}}\right)^{\mathrm{c}}$ \\
\hline 2 & 6d & 0.5 & 7d, 92 & $\mathbf{8 d}, 3$ & $93,4\left(S_{\mathrm{P}}\right)^{\mathrm{c}}$ \\
\hline 3 & $6 e$ & 0.5 & $7 e, 82$ & $\mathbf{8 e}, 4$ & $95,8\left(S_{\mathrm{P}}\right)^{\mathrm{c}}$ \\
\hline
\end{tabular}

\footnotetext{
${ }^{a}$ Determined by HPLC analysis on a chiral stationary phase (AS-H column, eluent: 9:1 hexane-isopropanol, $1 \mathrm{~mL} / \mathrm{min}, \lambda=252 \mathrm{~nm}$ ).

${ }^{\mathrm{b}}$ Estimated yield, due to the presence of starting material.

${ }^{c}$ The attribution of the configuration was made on the basis of previously reported data. ${ }^{21}$
}

Based on the above results, it was presumed that if the chiral group could be moved closer to the deprotonation site, the ees (des) could be improved; thus, secondary alcohols were next considered (Schemes 2 and 3, Table 4). Toward this purpose, (1R,2S)-N-(tert-butoxycarbonyl)ephedrine (5f), (2S,4R)-tert-butyl 4-hydroxy-2-(tert-butyldiphenylsilyloxymethyl)-1-pyrrolidinecarboxylate (5g), 5-O(tert-butyldiphenylsilyl)-1,2-O-isopropylidene- $\alpha$-D-xylofuranose $\quad(\mathbf{5 h}), \quad$ and $\quad 2,3: 5,6$-di-Ocyclohexylidene- $\alpha$-D-mannofuranose (5i) were converted to the corresponding ferrocene esters $\mathbf{6} \mathbf{f}-\mathbf{i}$ in good yields. When 6 f was consecutively treated by 0.5 equiv of the lithium-cadmium base and then iodine as before, the iodo ester $7 \mathbf{f}$ was isolated in $84 \%$ yield and an encouraging $30 \%$ ee $\left(S_{\mathrm{P}}\right)$, as 
determined after reduction to 2-iodoferrocenemethanol (9) (entry 1). Both the all TMP lithiumcadmium and lithium-zinc bases were tested for the functionalization of the other esters; starting from 6g, no reaction was noted upon contact with the lithium-cadmium base (entries 2 and 3). However, under the same reaction conditions, the use of the lithium-zinc base afforded the expected derivative $\mathbf{6 g}$ in $73 \%$ yield (entry 4). The reactions from $\mathbf{6 f}$ and $\mathbf{6 g}$ proceeded with similar diastereoselectivities (entries 1 and 4). Compound $\mathbf{6 h}$ was readily metalated using either 0.5 equiv of the lithium-cadmium base or 1 equiv of the lithium-zinc base; the $R_{\mathrm{P}}$ diastereoisomer was formed predominantly $(20 \%$ de, entries 5 and 6). Concerning $\mathbf{6 i}$, the metalation was not complete even with both kinds of base, and low to significant des were obtained in favor of the $S_{\mathrm{P}}$ (entries 7-9). It is pertinent to mention that it was possible to avoid the competitive dideprotonation reaction by modifying the $\mathrm{R}$ group of the ester, and that using excess of base could improve the diastereoselectivity (compare entries 7 and 8).

Table 4. Metalation of chiral ferrocenecarboxylates $\mathbf{6 f - i}$ using the bases in situ prepared from $\mathrm{MCl}_{2} \cdot$ TMEDA (x equiv) and Li(TMP) (3x equiv) followed by trapping with $\mathrm{I}_{2}$.

\begin{tabular}{|c|c|c|c|c|}
\hline Entry & Substrate, $\mathrm{R}$ & $\mathrm{M}, \mathrm{x}$ & 7, Yield $(\%)$, de $(\%)^{\mathrm{a}}$ & Yield $(\%)$ for 9 , ee $(\%)^{b}$ \\
\hline 1 & 6f & $\mathrm{Cd}, 0.5$ & $7 f, 84^{c}$ & $93,30\left(S_{\mathrm{P}}\right)^{\mathrm{d}}$ \\
\hline $\begin{array}{l}2 \\
3 \\
4\end{array}$ & $6 \mathrm{~g}$ & $\begin{array}{l}\mathrm{Cd}, 0.5 \\
\mathrm{Cd}, 1 \\
\mathrm{Zn}, 1\end{array}$ & $\begin{array}{l}\mathrm{e} \\
\mathrm{e} \\
7 \mathrm{~g}, 73\end{array}$ & $94,33\left(S_{\mathrm{P}}\right)^{\mathrm{d}}$ \\
\hline $\begin{array}{l}5 \\
6\end{array}$ & $6 h$ & $\begin{array}{l}\mathrm{Cd}, 0.5 \\
\mathrm{Zn}, 1\end{array}$ & $\begin{array}{l}\mathbf{7 h}, 78,20 \\
\mathbf{7 h}, 86,20\end{array}$ & $\begin{array}{l}50,22\left(R_{\mathrm{P}}\right)^{\mathrm{d}} \\
61,22\left(R_{\mathrm{P}}\right)^{\mathrm{d}}\end{array}$ \\
\hline $\begin{array}{l}7 \\
8 \\
9\end{array}$ & $6 \mathbf{i}$ & $\begin{array}{l}\mathrm{Cd}, 1 \\
\mathrm{Cd}, 1.5 \\
\mathrm{Zn}, 1\end{array}$ & $\begin{array}{l}7 \mathbf{7}, 38^{\mathrm{f}}, 27 \\
\mathbf{7 i}, 67^{\mathrm{f}}, 48 \\
7 \mathbf{i}, 50^{\mathrm{f}}, 17\end{array}$ & $\begin{array}{l}\left(S_{\mathrm{P}}\right)^{\mathrm{d}, \mathrm{g}} \\
\left(S_{\mathrm{P}}\right)^{\mathrm{d}, \mathrm{g}} \\
\left(S_{\mathrm{P}}\right)^{\mathrm{d}, \mathrm{g}}\end{array}$ \\
\hline
\end{tabular}

\footnotetext{
${ }^{\text {a }}$ When possible, determined from the integration of the ${ }^{1} \mathrm{H}$ NMR spectrum of the crude mixture.

${ }^{\mathrm{b}}$ Determined by HPLC analysis on a chiral stationary phase (AS-H column, eluent: 9:1 hexane-isopropanol, $1 \mathrm{~mL} / \mathrm{min}, \lambda=252 \mathrm{~nm}$ ).

${ }^{\mathrm{c}}$ The diiodide $\mathbf{8 f}$ was isolated in $9 \%$ yield.

${ }^{\mathrm{d}}$ The attribution of the configuration was made on the basis of previously reported data. ${ }^{21}$

e No reaction.

${ }^{\mathrm{f}}$ Estimated yield, due to the presence of starting material.

${ }^{\mathrm{g}}$ Reduction performed on a fraction.
} 
A thorough study was then undertaken in order to evaluate the parameters responsible for the diastereoselectivity with ferrocene carboxylate $\mathbf{6 j}$ derived from inexpensive diacetone-D-glucose $(\mathbf{5} \mathbf{j})$. Different reaction conditions were employed using lithium-cadmium bases (Table 5). Thus, the first reaction was performed as before using 1 equiv of the all TMP combination to furnish, after interception, the monoiodo derivative $7 \mathbf{j}$ in $85 \%$ yield and $74 \%$ de (entry 1 ). Using lower reaction temperatures (entries 2 and 3) or different reaction times (entries 4 and 5) had no effect on the conversion. Concerning the diastereoselectivity, reducing the reaction temperature from room temperature to $-20{ }^{\circ} \mathrm{C}$ led to a de decreased by about $10 \%$ (entry 3 ). Further, the reaction was performed using different solvents. $\mathrm{Et}_{2} \mathrm{O}$ and toluene were first compared with THF; both gave similar yields but lower des (entries 6 and 7). In the absence of $\mathrm{LiCl}$, the reaction carried out in toluene led to a lower conversion (entry 8). On the contrary, the reaction proved more efficient in the presence of TMEDA $(5$ equiv, 91\% yield), but to the detriment of the diastereoselectivity (54\% de, entry 9). Hexane was identified as a bad solvent for the reaction, giving the iodide $7 \mathbf{j}$ in $28 \%$ yield and $40 \%$ de (entry 10 ).

The deleterious effect of TMEDA ${ }^{22}$ (5 equiv) on the diastereoselectivity of the reaction performed in THF was demonstrated, affording a high $93 \%$ yield but a decreased de $(65 \%$ instead of $74 \%$ without additional TMEDA, entry 11). The similar negative effect of $\mathrm{LiCl}^{23}$ on the course of the reaction was evidenced by carrying out the reaction in the presence of 10 equiv of this salt: though a high yield was obtained, a lower de was recorded (60\% instead of $74 \%$ without additional salt, entry 12$)$. In order to chelate $\mathrm{LiCl}$ ( 2 equiv), which is generated in situ due to the reaction between $\mathrm{CdCl}_{2} \cdot \mathrm{TMEDA}$ and Li(TMP) (3 equiv), and check if any effect on the product profile could be seen, we attempted the use of $N, N, N^{\prime}, N^{\prime}$-tetraethylethylenediamine (TEEDA), a known lithium chelating ligand. ${ }^{24}$ Unfortunately, using additional TEEDA (5 equiv), the product de was lowered to $56 \%$, a result that could be due to a non-selective complexation of the lithium atoms of $\mathrm{LiCl}$ (entry 13).

When the reaction was carried out by discarding all TMEDA sources (i.e. using $\mathrm{CdCl}_{2}$ instead of $\mathrm{CdCl}_{2} \cdot \mathrm{TMEDA}$ to prepare the base), a better $82 \%$ de was obtained (entry 14 ). The de could be 
improved to $90 \%$ by adding the substrate to the base at room temperature instead of $0{ }^{\circ} \mathrm{C}$ (entry 15 ), but lower $\left(-30^{\circ} \mathrm{C}\right)$ or higher $\left(40^{\circ} \mathrm{C}\right)$ temperatures were less successful (entries 16 and 17$)$.

Table 5. Metalation of chiral ferrocenecarboxylates $\mathbf{6 j} \mathbf{j}, \mathbf{k}$ using lithium-cadmium combinations followed by trapping with $\mathrm{I}_{2}$.

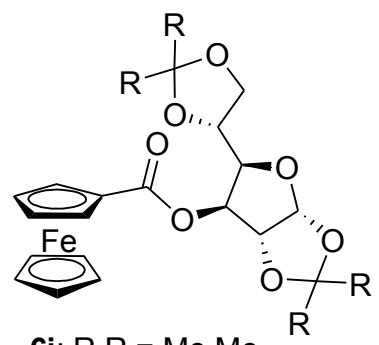

6j: $R, R=M e, M e$ 6k: $\mathrm{R}, \mathrm{R}=\left(\mathrm{CH}_{2}\right)_{5}$

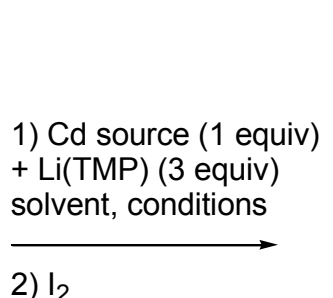

2) $\mathrm{I}_{2}$

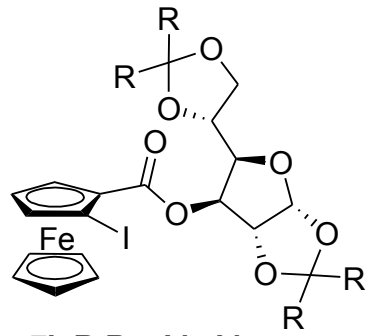

7j: $R, R=M e, M e$

$7 \mathbf{k}: \mathrm{R}, \mathrm{R}=\left(\mathrm{CH}_{2}\right)_{5}$
1) DIBAL-H

$\mathrm{THF}, 0^{\circ} \mathrm{C}, 1 \mathrm{~h}$

2) Hydrolysis

\begin{tabular}{|c|c|c|c|c|c|}
\hline Entry & 6 & Cd source & Solvent, conditions & $\begin{array}{l}\text { 7, Yield (\%), } \\
\text { de }(\%)^{\text {a }}\end{array}$ & $\begin{array}{l}\text { Yield }(\%) \text { for } \mathbf{9}, \\
\text { ee }(\%)^{\mathrm{b}}\end{array}$ \\
\hline 1 & 6j & $\mathrm{CdCl}_{2} \cdot \mathrm{TMEDA}$ & THF, rt, $2 \mathrm{~h}$ & $7 \mathbf{j}, 85,74$ & $89,71\left(S_{\mathrm{P}}\right)^{\mathrm{c}}$ \\
\hline 2 & & & $\mathrm{THF}, 0^{\circ} \mathrm{C}, 2 \mathrm{~h}$ & $7 \mathbf{j}, 87,75$ & $89,75\left(S_{\mathrm{P}}\right)^{\mathrm{c}}$ \\
\hline 3 & & & THF, $-20^{\circ} \mathrm{C}, 2 \mathrm{~h}$ & $7 \mathbf{j}, 93,65$ & \\
\hline 4 & $\mathbf{6 j}$ & $\mathrm{CdCl}_{2} \cdot \mathrm{TMEDA}$ & THF, rt, $0.5 \mathrm{~h}$ & $7 \mathbf{j}, 87,74$ & 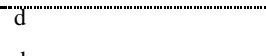 \\
\hline 5 & & & $\mathrm{THF}, \mathrm{rt}, 6 \mathrm{~h}$ & $7 \mathbf{j}, 91,74$ & d \\
\hline 6 & $6 \mathbf{j}$ & $\mathrm{CdCl}_{2} \cdot \mathrm{TMEDA}$ & $\mathrm{Et}_{2} \mathrm{O}, \mathrm{rt}, 2 \mathrm{~h}$ & $7 \mathbf{j}, 87,50$ & $94,51\left(S_{\mathrm{P}}\right)^{\mathrm{c}}$ \\
\hline 7 & & & PhMe, rt, 2 h & $7 \mathbf{j}, 81,66$ & \\
\hline $8^{\mathrm{e}}$ & & & PhMe, rt, 2 h & $7 \mathbf{j}, 74,64$ & d \\
\hline 9 & & & PhMe, TMEDA ( 5 equiv), $\mathrm{rt}, 2 \mathrm{~h}$ & $7 \mathbf{j}, 91,54$ & $94,52\left(S_{\mathrm{P}}\right)^{\mathrm{c}}$ \\
\hline 10 & & & HexH, TMEDA ( 5 equiv), rt, $2 \mathrm{~h}$ & $7 \mathbf{j}, 28^{\mathrm{f}}, 40$ & $90,37\left(S_{\mathrm{P}}\right)^{\mathrm{c}}$ \\
\hline 11 & $\mathbf{6 j}$ & $\mathrm{CdCl}_{2} \cdot \mathrm{TMEDA}$ & THF, TMEDA (5 equiv), rt, $2 \mathrm{~h}$ & $7 \mathbf{j}, 93,65$ & d \\
\hline 12 & & & THF, $\mathrm{LiCl}$ (10 equiv), rt, $2 \mathrm{~h}$ & $7 \mathbf{j}, 93,60$ & d \\
\hline 13 & & & THF, TEEDA ( 5 equiv), $\mathrm{rt}, 2 \mathrm{~h}$ & $7 \mathbf{j}, 52,56$ & d \\
\hline $14^{\mathrm{g}}$ & $6 \mathbf{j}$ & $\mathrm{CdCl}_{2}$ & THF, rt, $2 \mathrm{~h}$ & $7 \mathbf{j}, 87,82$ & d \\
\hline $15^{\mathrm{h}}$ & & & THF, rt, $2 \mathrm{~h}$ & $7 \mathbf{j}, 74,90$ & d \\
\hline $16^{\mathrm{i}}$ & & & $\mathrm{THF},-30$ to $5^{\circ} \mathrm{C}$ in $2 \mathrm{~h}$ & $7 \mathbf{j}, 93,70$ & $\mathrm{~d}$ \\
\hline $17^{\mathrm{j}}$ & & & THF, $40-50{ }^{\circ} \mathrm{C}, 2 \mathrm{~h}$ & $7 \mathbf{j}, 89,61$ & d \\
\hline $18^{\mathrm{k}}$ & $6 j$ & $\mathrm{CdCl}_{2} \cdot \mathrm{TMEDA}$ & THF, rt, $2 \mathrm{~h}$ & $7 \mathbf{j}, 77,61$ & $93,57\left(S_{\mathrm{P}}\right)^{\mathrm{c}}$ \\
\hline 19 & 6k & $\mathrm{CdCl}_{2} \cdot \mathrm{TMEDA}$ & THF, rt, $2 \mathrm{~h}$ & $7 \mathbf{k}, 93,54$ & $94,58\left(S_{\mathrm{P}}\right)^{\mathrm{c}}$ \\
\hline
\end{tabular}

${ }^{a}$ Determined from the integration of the ${ }^{1} \mathrm{H}$ NMR spectrum of the crude mixture.

${ }^{\mathrm{b}}$ Determined by HPLC analysis on a chiral stationary phase (AS-H column, eluent: 9:1 hexane-isopropanol, $1 \mathrm{~mL} / \mathrm{min}, \lambda=252 \mathrm{~nm}$ ).

${ }^{c}$ The attribution of the configuration was made on the basis of previously reported data. ${ }^{21}$

${ }^{\mathrm{d}}$ Reduction not performed.

${ }^{\mathrm{e}} \mathbf{6} \mathbf{j}$ was added after removal of $\mathrm{LiCl}$ by filtration.

${ }^{\mathrm{f}}$ Estimated yield, due to the presence of starting material.

${ }^{\mathrm{g}}$ Substrate added at $0{ }^{\circ} \mathrm{C}$.

${ }^{\mathrm{h}}$ Substrate added at room temperature.

${ }^{\mathrm{i}}$ Substrate added at $-30^{\circ} \mathrm{C}$.

${ }^{\mathrm{j}}$ Substrate added at $40{ }^{\circ} \mathrm{C}$.

${ }^{\mathrm{k}}$ Using the base in situ prepared from $\mathrm{CdCl}_{2} \cdot \mathrm{TMEDA}$ (1 equiv), $\mathrm{Li}(\mathrm{TMP})$ (2 equiv) and BuLi (1 equiv).

In order to check the importance of the composition of the base on the course of the reaction, the use of a reagent in situ prepared from $\mathrm{CdCl}_{2} \cdot \mathrm{TMEDA}$ ( 1 equiv), $\mathrm{Li}(\mathrm{TMP})\left(2\right.$ equiv) and BuLi ( 1 equiv) ${ }^{8 \mathrm{c}}$ was attempted; upon reaction in THF at room temperature, the deprotonation still took place albeit 
resulting in a lower yield but with a $61 \%$ de (against $74 \%$ using the all TMP base, entry 18). Additionally, in a bid to improve the diastereoselectivities, the protective group of the diol was modified from a diisopropylidene to a dicyclohexylidene. When the derivative $\mathbf{6 k}$ was employed in the reaction instead of the corresponding derivative $\mathbf{6 j}$, a $54 \%$ de was obtained against $74 \%$ when $\mathbf{6} \mathbf{j}$ was the chiral ester (entry 19).

Lithium-zinc combinations were also employed to attempt the diastereoselective deproto-metalation of ferrocene carboxylate $\mathbf{6 j}$ (Table 6). The first reaction was performed using 1 equiv of the all TMP base in THF at room temperature for $2 \mathrm{~h}$. After interception as before, the iodide $\mathbf{7 j}$ was isolated in $86 \%$ yield and 54\% de (entry 1), a result less interesting than that obtained with the corresponding lithiumcadmium base (Table 5, entry 1). By performing the reaction at $-30{ }^{\circ} \mathrm{C}$ or $-50{ }^{\circ} \mathrm{C}$ using the base prepared from $\mathrm{ZnCl}_{2} \cdot \mathrm{TMEDA}$ ( 1 equiv) and $\mathrm{Li}(\mathrm{TMP}$ ) (4 equiv), the de was increased by about $10 \%$ (entries 2 and 3). In contrast, when the reaction mixture was warmed to room temperature after combining base and substrate at $-30{ }^{\circ} \mathrm{C}$, a moderate $53-56 \%$ de (similar to that obtained under the conditions described for entry 1) was noted (entries 4-6). By using the base prepared from $\mathrm{ZnCl}_{2}$ instead of $\mathrm{ZnCl}_{2} \cdot \mathrm{TMEDA}$, the efficiency of the deproto-metalation was lowered, even when TMEDA (1 equiv) was present in THF at the beginning of the reaction (entry 5) or added later (entry 6). Lower yields and des were noted by using hexane containing 5 equiv of TMEDA $^{7 \mathrm{a}}$ or dimethoxymethane (DMM) as solvent (entries 7 and 8).

The base prepared from $\mathrm{ZnCl}_{2} \cdot \mathrm{TMEDA}$ ( 1 equiv) and $\mathrm{Li}(\mathrm{TMP})$ (3 equiv) being a 1:1 mixture of $\mathrm{Zn}(\mathrm{TMP})_{2}$ and Li(TMP), ${ }^{7 \mathrm{i}}$ the effect on the diastereoselectivity of adding separately both amides was studied. To this purpose, the addition to a THF solution of the substrate $\mathbf{6}$ f containing $\mathrm{ZnCl}_{2} \cdot \mathrm{TMEDA}$ (1 equiv) and Li(TMP) (2 equiv) of a THF solution of Li(TMP) (1 or 2 equiv) was attempted. After $2 \mathrm{~h}$ stirring at this temperature and iodolysis, the de was slightly improved to reach 64 or $72 \%$, respectively (entries 9 and 10). A similar diastereoselectivity was obtained by adding Li(TMP) (3 equiv) to a mixture of $\mathrm{ZnCl}_{2} \cdot \mathrm{TMEDA}$ and $\mathbf{6 f}$ under the same conditions (entry 11). 
In the case of the lithium-zinc base, a deleterious effect of TMEDA on the diastereoselectivity was not observed (54\% de with and without TMEDA, entry 12). In the case of the mixed lithium-zinc base, replacing one TMP by a butyl group ${ }^{7 \mathrm{e}}$ did not reduce the diastereoselectivity, and a 55\% de (entry 13), slightly lower than that noted using the corresponding lithium-cadmium base (Table 5, entry 18), was obtained. The impact of the diol protection was also checked using the all TMP lithium-zinc base; no difference was noticed between the diisopropylidene $\mathbf{6 j}$ and the corresponding dicyclohexylidene $\mathbf{6 k}$ (entry 14).

Table 6. Metalation of chiral ferrocenecarboxylates $\mathbf{6 j}, \mathbf{k}$ using lithium-zinc combinations followed by trapping with $\mathrm{I}_{2}$.

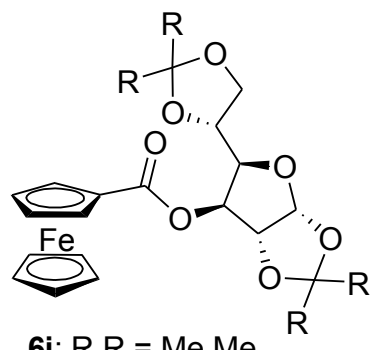

6j: $R, R=M e, M e$ 6k: $\mathrm{R}, \mathrm{R}=\left(\mathrm{CH}_{2}\right)_{5}$
1) Zn source (1 equiv)

$+\mathrm{Li}(\mathrm{TMP})$ (2 equiv)

+ RLi (x equiv)

solvent, conditions

2) $\mathrm{I}_{2}$

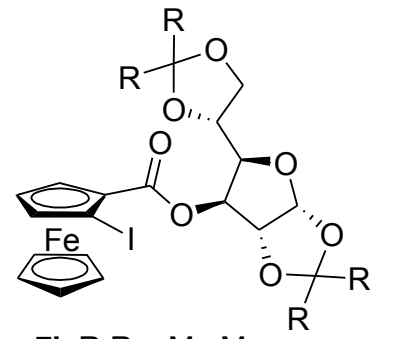

7j: $\mathrm{R}, \mathrm{R}=\mathrm{Me}, \mathrm{Me}$
1) DIBAL-H THF, $0^{\circ} \mathrm{C}, 1 \mathrm{~h}$ 2) Hydrolysis

\begin{tabular}{|c|c|c|c|c|c|}
\hline Entry & 6 & Zn source & $\mathrm{R}(\mathrm{x})$ & Solvent, conditions & 7 , Yield $(\%)$, de $(\%)^{\mathrm{a}}$ \\
\hline 1 & $\mathbf{6 j}$ & $\mathrm{ZnCl}_{2} \cdot \mathrm{TMEDA}$ & TMP (1) & THF, rt, $2 \mathrm{~h}$ & $\mathbf{7 j}, 86,54\left(S_{\mathrm{P}}\right)^{\mathrm{b}}$ \\
\hline 2 & 6j & $\mathrm{ZnCl}_{2} \cdot \mathrm{TMEDA}$ & TMP (2) & $\mathrm{THF},-30^{\circ} \mathrm{C}, 2 \mathrm{~h}$ & $\mathbf{7 j}, 82,66\left(S_{\mathrm{P}}\right)^{\mathrm{b}}$ \\
\hline $3^{c}$ & & $\mathrm{ZnCl}_{2} \cdot \mathrm{TMEDA}$ & TMP (2) & $\mathrm{THF},-50^{\circ} \mathrm{C}, 5 \mathrm{~h}$ & $7 \mathbf{j}, 71,65\left(S_{\mathrm{P}}\right)^{\mathrm{b}}$ \\
\hline 4 & & $\mathrm{ZnCl}_{2} \cdot \mathrm{TMEDA}$ & TMP (2) & $\mathrm{THF},-30{ }^{\circ} \mathrm{C}$ to $\mathrm{rt}, 2 \mathrm{~h}$ & $7 \mathbf{j}, 86,56\left(S_{\mathrm{P}}\right)^{\mathrm{b}}$ \\
\hline 5 & & $\mathrm{ZnCl}_{2}$ & TMP (2) & THF, TMEDA ( 1 equiv), $-30{ }^{\circ} \mathrm{C}$ to $\mathrm{rt}, 2 \mathrm{~h}$ & $7 \mathbf{j}, 30,56\left(S_{\mathrm{P}}\right)^{\mathrm{b}}$ \\
\hline $6^{\mathrm{d}}$ & & $\mathrm{ZnCl}_{2}$ & $\operatorname{TMP}(2)$ & THF, TMEDA ( 1 equiv), $-30{ }^{\circ} \mathrm{C}$ to $\mathrm{rt}, 2 \mathrm{~h}$ & $7 \mathbf{j}, 46,53\left(S_{\mathrm{P}}\right)^{\mathrm{b}}$ \\
\hline 7 & $6 \mathbf{j}$ & $\mathrm{ZnCl}_{2} \cdot \mathrm{TMEDA}$ & TMP (1) & HexH, TMEDA (5 equiv), rt, 2 h & $7 \mathbf{j}, 50,42\left(S_{\mathrm{P}}\right)^{\mathrm{b}, \mathrm{e}}$ \\
\hline 8 & & $\mathrm{ZnCl}_{2}$ & $\operatorname{TMP}(2)$ & $\mathrm{DMM}, \mathrm{rt}, 2 \mathrm{~h}$ & $7 \mathbf{j}, 32,51\left(S_{\mathrm{P}}\right)^{\mathrm{b}}$ \\
\hline$\overline{9^{f}}$ & $6 \mathbf{j}$ & $\mathrm{ZnCl}_{2} \cdot \mathrm{TMEDA}$ & TMP (1) & THF, rt, 2 h & $\mathbf{7 j}, 89,64\left(S_{\mathrm{P}}\right)^{\mathrm{b}}$ \\
\hline $10^{\mathrm{f}}$ & & $\mathrm{ZnCl}_{2} \cdot \mathrm{TMEDA}$ & TMP (2) & $\mathrm{THF},-30{ }^{\circ} \mathrm{C}$ to $\mathrm{rt}, 2 \mathrm{~h}$ & $7 \mathbf{j}, 87,72\left(S_{\mathrm{P}}\right)^{\mathrm{b}}$ \\
\hline 11 & & $\mathrm{ZnCl}_{2} \cdot \mathrm{TMEDA}$ & $\mathrm{g}$ & THF, $-30{ }^{\circ} \mathrm{C}$ to $\mathrm{rt}, 2 \mathrm{~h}$ & $7 \mathbf{j}, 70,68\left(S_{\mathrm{P}}\right)^{\mathrm{b}}$ \\
\hline 12 & $6 \mathbf{j}$ & $\mathrm{ZnCl}_{2}$ & TMP (1) & THF, rt, $2 \mathrm{~h}$ & $7 \mathbf{j}, 68,54\left(S_{\mathrm{P}}\right)^{\mathrm{b}}$ \\
\hline $13^{\mathrm{h}}$ & $6 \mathbf{j}$ & $\mathrm{ZnCl}_{2} \cdot \mathrm{TMEDA}$ & $\mathrm{Bu}(1)$ & THF, rt, $2 \mathrm{~h}$ & $7 \mathbf{j}, 89,55\left(S_{\mathrm{P}}\right)^{b, i}$ \\
\hline$\overline{14}$ & $6 \mathbf{k}$ & $\mathrm{ZnCl}_{2} \cdot \mathrm{TMEDA}$ & TMP (1) & THF, rt, $2 \mathrm{~h}$ & $7 \mathbf{k}, 87,56\left(S_{\mathrm{P}}\right)^{b, j}$ \\
\hline
\end{tabular}

\footnotetext{
${ }^{\text {a }}$ Determined from the integration of the ${ }^{1} \mathrm{H}$ NMR spectrum of the crude mixture.

${ }^{b}$ The attribution of the configuration was made on the basis of previously reported data. ${ }^{21}$

${ }^{\mathrm{c}}$ Base transferred to the substrate.

d TMEDA slowly added at $-30{ }^{\circ} \mathrm{C}$.

${ }^{\mathrm{e}}$ Reduction using DIBAL-H provided the alcohol 9 in $94 \%$ yield and $42 \%$ ee $\left(S_{\mathrm{P}}\right)$.

${ }^{\mathrm{f}}$ Sequential addition of Li(TMP) (2 equiv) and, 10 min later, RLi (1 or 2 equiv).

${ }^{\mathrm{g}}$ Substrate mixed with $\mathrm{ZnCl}_{2} \cdot \mathrm{TMEDA}$ before addition of $\mathrm{Li}(\mathrm{TMP})$ ( 3 equiv).

${ }^{\mathrm{h}}$ Using the base in situ prepared from $\mathrm{ZnCl}_{2} \cdot$ TMEDA (1 equiv), Li(TMP) (2 equiv) and BuLi (1 equiv).

${ }^{\text {I }}$ Reduction using DIBAL-H provided the alcohol 9 in $93 \%$ yield and $60 \%$ ee $\left(S_{\mathrm{P}}\right)$.

${ }^{\mathrm{j}}$ Reduction using DIBAL-H provided the alcohol 9 in $96 \%$ yield and $57 \%$ ee $\left(S_{\mathrm{P}}\right)$.
} 
Double asymmetric induction ${ }^{25}$ was attempted using commercial $(R)$ - and $(S)$-bis(1phenylethyl)amine as ligand source instead of 2,2,6,6-tetramethylpiperidine. When $\mathbf{6 j}$ was reacted with a base prepared from $\mathrm{ZnCl}_{2} \cdot \mathrm{TMEDA}(1$ equiv) and the $(R)$ or $(S)$ lithium amide (3 equiv), the iodide $7 \mathbf{j}$ was obtained in 67 and 24\% yield, and 79 and $10 \%$ de in favor of the $\left(S_{\mathrm{P}}\right)$-diastereoisomer, respectively. In addition, upon treatment by a base prepared from $\mathrm{CdCl}_{2}$ (1 equiv) and the $(R)$ lithium amide ( 3 equiv) under the same reaction conditions, the iodide $7 \mathbf{j}$ was obtained in $97 \%$ yield, and $80 \%$ de. The sequential addition to a THF solution of the substrate $\mathbf{6 j}$ containing $\mathrm{ZnCl}_{2} \cdot \mathrm{TMEDA}(1$ equiv) at room temperature of two THF solutions of $(R)$ lithium amide (2 equiv) at 10 min interval was next attempted. Trapping using iodine after $2 \mathrm{~h}$ contact led to both good yield and de (Scheme 4).

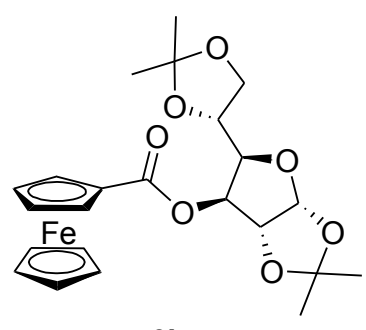

6j
1) $\mathrm{ZnCl}_{2} \cdot \mathrm{TMEDA}$ (1 equiv)

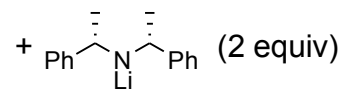

THF, rt, $10 \mathrm{~min}$

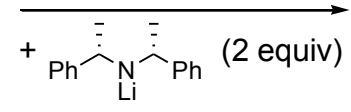

THF, rt, $2 \mathrm{~h}$

2) $I_{2}$

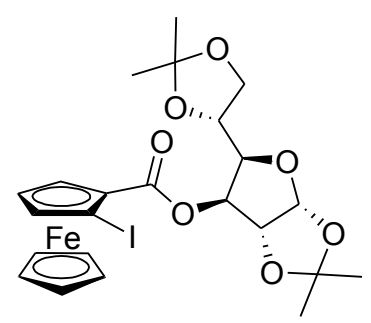

7j: $85 \%$ yield, $91 \%$ de

Scheme 4. Metalation of chiral ferrocenecarboxylate $\mathbf{6 j}$ using a chiral lithium-zinc combination followed by trapping with $\mathrm{I}_{2}$.

By involving in similar reactions the ester $\mathbf{6 1}$, which differs from $\mathbf{6} \mathbf{j}$ at the $\mathrm{C} 3$ configuration of the sugar substituent, a good conversion to the iodide 71 was observed (64 and $82 \%$ yield using the all TMP lithium-cadmium and lithium-zinc base, respectively) but with a disappointing excess in favor of the $S_{\mathrm{P}}$ diastereoisomer (32\% ee in both cases, Scheme 5).

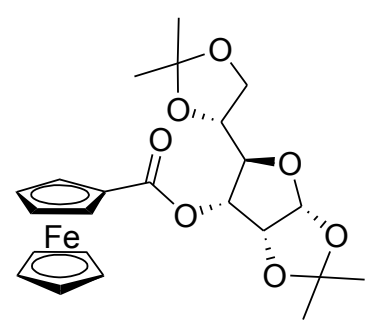

6I

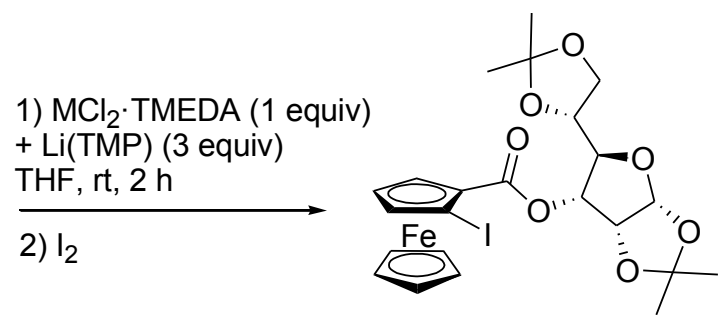

71: $82 \%$ yield $(M=C d)$ $64 \%$ yield $(M=Z n)$
1) DIBAL-H

THF, $0{ }^{\circ} \mathrm{C}, 1 \mathrm{~h}$

2) Hydrolysis

$95 \%$ yield, $32 \%$ ee $(M=C d)$ $86 \%$ yield, $32 \%$ ee $(M=Z n)$

Scheme 5. Metalation of chiral ferrocenecarboxylate 61 using lithium-cadmium and lithium-zinc bases followed by trapping with $\mathrm{I}_{2}$. 
In order to evaluate chains more coordinating toward metals, we considered the reaction of the ferrocenecarboxylate $\mathbf{6 m}$ (Table 7), generated from 5-(tert-butoxycarbonylamino)-5-deoxy-1,2-Oisopropylidene- $\alpha$-D-xylofuranose (5m), as the next example. Upon reaction with 1 equiv of the all TMP lithium-cadmium base, $\mathbf{6 m}$ was converted to the corresponding iodide $\mathbf{7 m}$ in $84 \%$ yield and in moderate diastereoselectivity (entry 1). In order to improve the diastereoselectivity, pre-treating the substrate with 1 equiv of an organolithium reagent for abstracting the $\mathrm{NH}$ proton was considered. The selectivity could be improved but at the cost of the yields (entries 2 and 3). As observed with previous substrates, the lithium-zinc base proved less efficient (entries 4 and 5).

Table 7. Metalation of chiral ferrocenecarboxylates $6 \mathbf{m}$ (or a lithium derivative) using lithiumcadmium and lithium-zinc bases followed by trapping with $\mathrm{I}_{2}$.
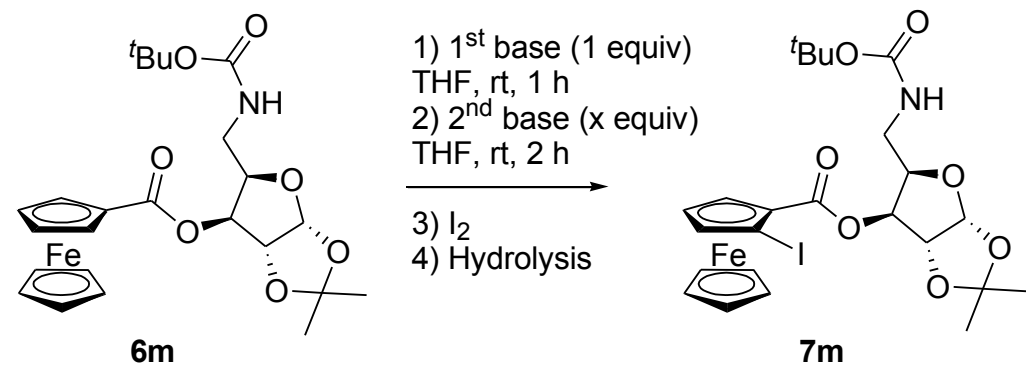

1) DIBAL-H

THF, $0^{\circ} \mathrm{C}, 1 \mathrm{~h}$

2) Hydrolysis

$6 m$

$7 \mathrm{~m}$

\begin{tabular}{|c|c|c|c|c|}
\hline Entry & $1^{\text {st }}$ base & $2^{\text {nd }}$ base $(x)$ & Yield $(\%)$ for $\mathbf{7 m}$, de $(\%)^{a}$ & Yield $(\%)$ for 9 , ee $(\%)^{b}$ \\
\hline 1 & - & $\mathrm{CdCl}_{2} \cdot \mathrm{TMEDA}(1)+\mathrm{Li}(\mathrm{TMP})(3)$ & 84 & $92,32\left(S_{\mathrm{P}}\right)^{\mathrm{c}}$ \\
\hline 2 & $\mathrm{BuLi}$ & $\mathrm{CdCl}_{2} \cdot \operatorname{TMEDA}(0.5)+\mathrm{Li}(\mathrm{TMP})(1.5)$ & 48 & $94,40\left(S_{\mathrm{P}}\right)^{\mathrm{c}}$ \\
\hline 3 & $\mathrm{MeLi}$ & $\mathrm{CdCl}_{2} \cdot \mathrm{TMEDA}(0.75)+\mathrm{Li}(\mathrm{TMP})(2.25)$ & 52,52 & $96,56\left(S_{\mathrm{P}}\right)^{\mathrm{c}}$ \\
\hline 4 & - & $\mathrm{ZnCl}_{2} \cdot \mathrm{TMEDA}(1)+\mathrm{Li}(\mathrm{TMP})(3)$ & 40 & d \\
\hline 5 & - & $\mathrm{ZnCl}_{2} \cdot \mathrm{TMEDA}(1.5)+\mathrm{Li}(\mathrm{TMP})(4.5)$ & 70 & $91,11\left(S_{\mathrm{P}}\right)^{\mathrm{c}}$ \\
\hline
\end{tabular}

${ }^{a}$ When possible, determined from the integration of the ${ }^{1} \mathrm{H}$ NMR spectrum of the crude mixture.

${ }^{b}$ Determined by HPLC analysis on a chiral stationary phase (AS-H column, eluent: 9:1 hexane-isopropanol, $1 \mathrm{~mL} / \mathrm{min}, \lambda=252 \mathrm{~nm}$ ).

${ }^{c}$ The attribution of the configuration was made on the basis of previously reported data. ${ }^{21}$

${ }^{\mathrm{d}}$ Reduction not performed.

The ferrocenecarboxylate 6n, synthesized from 6-(tert-butoxycarbonylamino)-6-deoxy-3-O-methyl1,2-O-isopropylidene- $\alpha$-D-glucofuranose (5n), showed better results (Table 8). Consecutive treatment with butyllithium ( 1 equiv) and the all TMP lithium-cadmium base ( 0.5 equiv) afforded the iodide $7 \mathbf{n}$ in $28 \%$ yield and an estimated $60 \%$ de, this time in favor of the $R_{\mathrm{P}}$ diastereoisomer (entry 1 ). Without butyllithium and using 1 equiv of base, the yield was improved, and a similar diastereoselectivity obtained. Under these conditions, both diastereoisomers were separated by column chromatography 
over silica gel (entry 2). The main stereoisomer $\boldsymbol{R}_{\mathbf{P}} \mathbf{- 7 n}$ was notably isolated in $34 \%$ yield and $98 \%$ de and identified unambiguously through its reduction with DIBAL-H to afford $\boldsymbol{R}-9$. More importantly, the corresponding but less toxic lithium-zinc base led to similar results $35 \%$ yield and $96 \%$ de for the stereoisomer $\boldsymbol{R}_{\mathbf{P}} \mathbf{- 7 n}$, entry 3). When applied to the ester $\mathbf{6 n}$, the sequential addition of two THF solutions, a first prepared from $\mathrm{ZnCl}_{2} \cdot \mathrm{TMEDA}$ or $\mathrm{ZnCl}_{2}$ (1 equiv) and $\mathrm{Li}(\mathrm{TMP})$ (2 equiv) and, 15 min later, a second of Li(TMP) (2 equiv) afforded $\boldsymbol{R}_{\mathbf{P}^{-}} \mathbf{7 n}$ in 51 and 57\% yield, respectively (entries 4 and 5).

Table 8. Metalation of chiral ferrocenecarboxylates 6n (or a lithium derivative) using lithium-cadmium and lithium-zinc bases followed by trapping with $\mathrm{I}_{2}$.
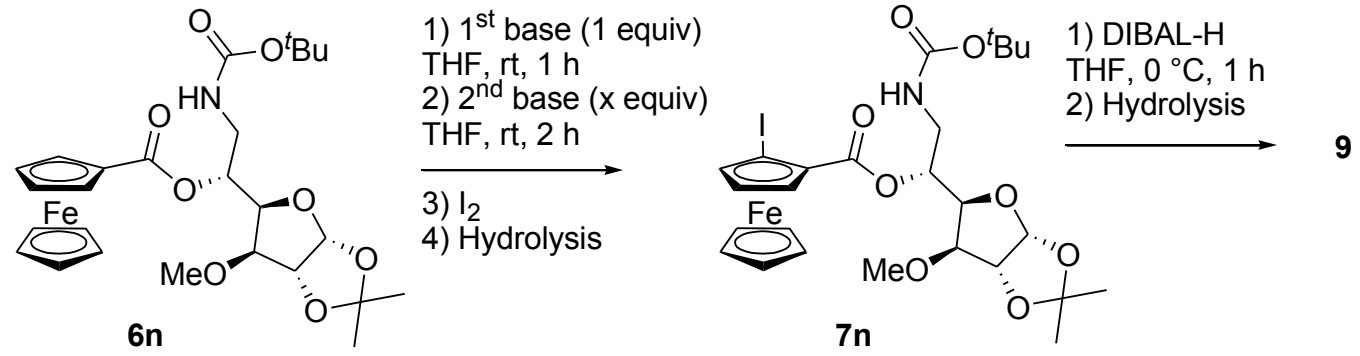

\begin{tabular}{|c|c|c|c|c|}
\hline Entry & $1^{\text {st }}$ base & $2^{\text {nd }}$ base $(x)$ & Yield (\%) for $\mathbf{7 n}$ & Yield $(\%)$ for 9 , ee $(\%)^{a}$ \\
\hline 1 & $\mathrm{BuLi}$ & $\mathrm{CdCl}_{2} \cdot \mathrm{TMEDA}(0.5)+\mathrm{Li}(\mathrm{TMP})(1.5)$ & $28^{\mathrm{b}}$ & $92,60\left(R_{\mathrm{P}}\right)^{\mathrm{c}}$ \\
\hline 2 & - & $\mathrm{CdCl}_{2} \cdot \mathrm{TMEDA}_{(1)}+\mathrm{Li}(\mathrm{TMP})(3)$ & $34\left(\boldsymbol{R}_{\mathbf{P}^{-}} \mathbf{7 n}\right) ; 16^{\mathrm{d}}\left(\boldsymbol{S}_{\mathbf{P}^{-}} \mathbf{7 n}\right)^{\mathrm{e}, \mathrm{f}}$ & $90,98\left(R_{\mathrm{P}}\right)^{\mathrm{c}} ; 91,93\left(S_{\mathrm{P}}\right)^{\mathrm{c}}$ \\
\hline$\overline{3}$ & - & $\mathrm{ZnCl}_{2} \cdot \mathrm{TMEDA}(1)+\mathrm{Li}(\mathrm{TMP})(3)$ & $35\left(\boldsymbol{R}_{\mathbf{P}}-\mathbf{7 n}\right) ; 12^{\mathrm{d}}\left(\boldsymbol{S}_{\mathbf{P}}-\mathbf{7 n}\right)^{\mathrm{f}}$ & $81,96\left(R_{\mathrm{P}}\right)^{\mathrm{c}} ; 88,92\left(S_{\mathrm{P}}\right)^{\mathrm{c}}$ \\
\hline 4 & - & $\mathrm{ZnCl}_{2} \cdot \mathrm{TMEDA}(1)+\mathrm{Li}(\mathrm{TMP})(2+2)$ & $51\left(\boldsymbol{R}_{\mathbf{P}}-7 \mathbf{n}\right)^{\mathrm{g}}$ & $\mathrm{h}$ \\
\hline 5 & - & $\mathrm{ZnCl}_{2}(1)+\mathrm{Li}(\mathrm{TMP})(2+2)^{\mathrm{i}}$ & $57\left(\boldsymbol{R}_{\mathbf{P}}-7 \mathbf{n}\right)^{\mathrm{g}}$ & $\mathrm{h}$ \\
\hline
\end{tabular}

\footnotetext{
${ }^{a}$ Determined by HPLC analysis on a chiral stationary phase (AS-H column, eluent: 9:1 hexane-isopropanol, $1 \mathrm{~mL} / \mathrm{min}, \lambda=252 \mathrm{~nm}$ ).

${ }^{\mathrm{b}}$ The diiodide $8 \mathrm{n}$ was also isolated in $12 \%$ yield.

${ }^{c}$ The attribution of the configuration was made on the basis of previously reported data. ${ }^{21}$

${ }^{\mathrm{d}}$ Estimated yield.

${ }^{\mathrm{e}}$ The diiodide $\mathbf{8 n}$ was also isolated in $37 \%$ yield.

${ }^{\mathrm{f}}$ Both diastereoisomers were separated during the purification by column chromatography over silica gel.

${ }^{\mathrm{g}}$ Isolation of the other diastereoisomer not performed.

${ }^{\mathrm{h}}$ Reduction not performed.

${ }^{\mathrm{i}}$ Sequential addition to the substrate of a THF solution prepared from $\mathrm{ZnCl}_{2} \cdot \mathrm{TMEDA}$ ( 1 equiv) and $\mathrm{Li}(\mathrm{TMP})(2 \mathrm{equiv})$ and, 10 min later, a THF solution of $\operatorname{Li}(\mathrm{TMP})$ (2 equiv).
}

Lithiation experiments on aryl carboxamides showed that the orientation of the functional group has an impact on the efficiency of the metalations at the ortho position. In particular, the coplanarity of the oxygen and activated hydrogen within the ring favors the reaction. ${ }^{26}$ We first compared the dihedral angle between the upper plane of the ferrocenyl moiety and the ester from the crystal structures of $\mathbf{6 c}$, 6d, 6e, 6i, 6j, 6k and $\mathbf{6 l}$ obtained (Figure 1) with the planar configuration of the main diastereoisomer of 7c, 7d, 7e, 7i , 7j, 7k and $7 \mathbf{l}$ observed (Table 9). Except in the case of $\mathbf{6 d}$ and $\mathbf{6 e}$, for which des below 
$10 \%$ were recorded, a dihedral angle of about $180^{\circ}$ corresponds to major formation of the $R_{\mathrm{P}}$ diastereoisomer and a dihedral angle of about $0^{\circ}$ to major formation of the $S_{\mathrm{P}}$ diastereoisomer.

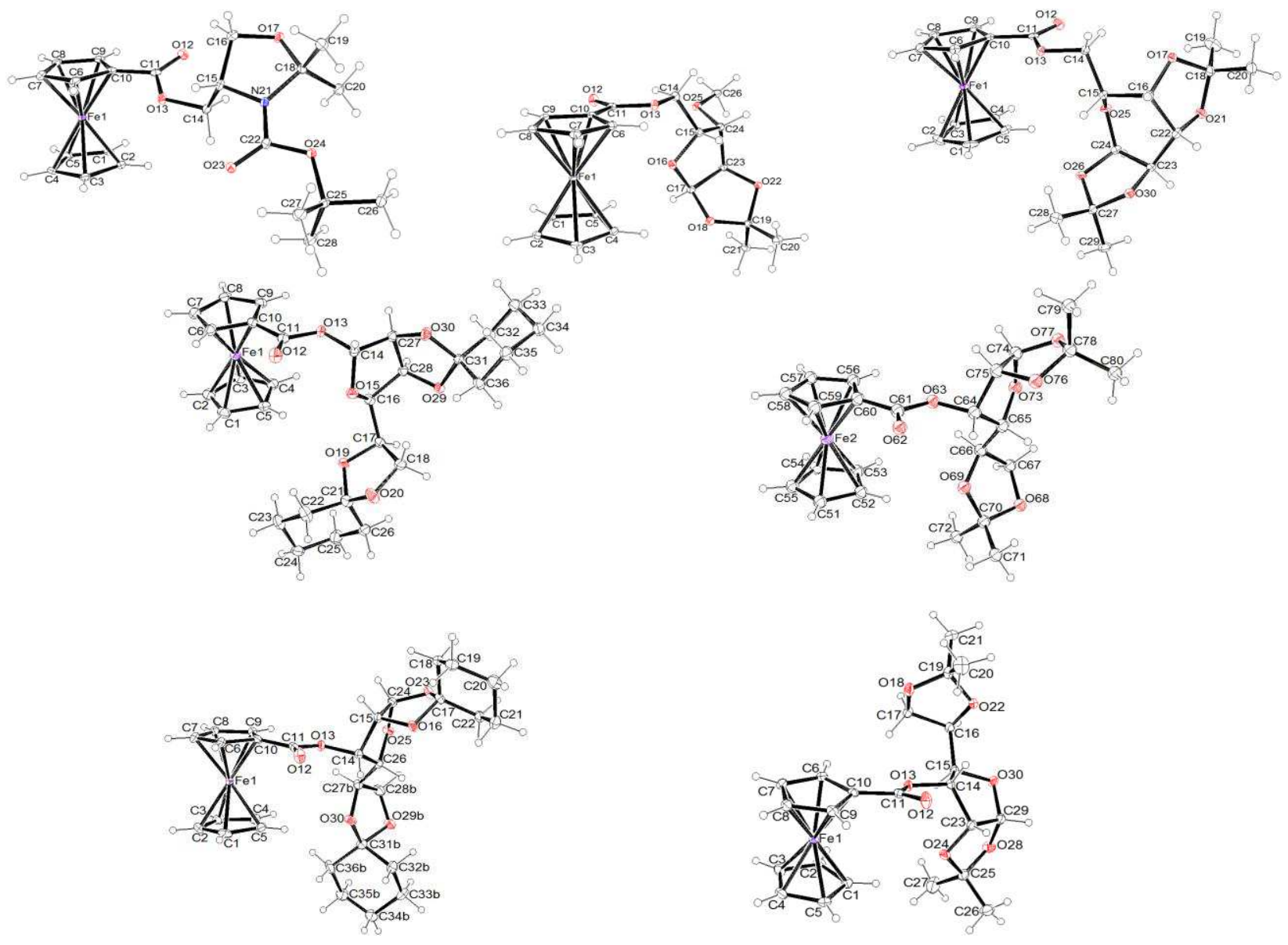

Figure 1. ORTEP diagram (30\% probability) of $\mathbf{6 c}, \mathbf{6 d}, \mathbf{6 e}, \mathbf{6 i}, \mathbf{6 j}, \mathbf{6 k}$ and $\mathbf{6 1}$.

Table 9. Dihedral angle between the upper plane of the ferrocenyl moiety and the ester for $\mathbf{6 c}, \mathbf{6 d}, \mathbf{6 e}$, $\mathbf{6 i}, \mathbf{6 j}, \mathbf{6 k}$ and $\mathbf{6 l}$, and expected and observed planar configurations for $\mathbf{7 .}$

\begin{tabular}{lllll}
\hline Entry & $\mathbf{6}$ & Dihedral angle & Expected planar configuration & Observed planar configuration \\
\hline 1 & $\mathbf{6 c}$ & about $180^{\circ}$ & $R_{\mathrm{P}}$ & $R_{\mathrm{P}}(14 \% \mathrm{de})$ \\
2 & $\mathbf{6 d}$ & about $180^{\circ}$ & $R_{\mathrm{P}}$ & $S_{\mathrm{P}}(4 \% \mathrm{de})$ \\
3 & $\mathbf{6 e}$ & about $180^{\circ}$ & $R_{\mathrm{P}}$ & $S_{\mathrm{P}}(8 \% \mathrm{de})$ \\
4 & $\mathbf{6 i}$ & about $0^{\circ}$ & $S_{\mathrm{P}}$ & $S_{\mathrm{P}}(48 \% \mathrm{de})$ \\
5 & $\mathbf{6 j}$ & about $0^{\circ}$ & $S_{\mathrm{P}}$ & $S_{\mathrm{P}}(90 \% \mathrm{de})$ \\
6 & $\mathbf{6 k}$ & about $0^{\circ}$ & $S_{\mathrm{P}}$ & $S_{\mathrm{P}}(56 \% \mathrm{de})$ \\
7 & $\mathbf{6}$ & about $0^{\circ}$ & $S_{\mathrm{P}}$ & $S_{\mathrm{P}}(32 \% \mathrm{de})$ \\
\hline
\end{tabular}

We next attempted a rationalization of the diastereoselectivity observed through DFT calculations. While the solid-state structure of $\mathbf{6} \mathbf{j}$ was obtained, we investigated the conformation of $\mathbf{6} \mathbf{j}$ in solution, which should affect the reaction outcome. In order to identify more stable conformers, geometrical 
(local stabilization) optimization was performed by changing the dihedral angle between the upper plane of the ferrocenyl moiety and the ester carbonyl group (B3LYP/6-31G(d), structure of the ferrocenyl group fixed). The dihedral angle was fixed with $30^{\circ}$ intervals from $0^{\circ}$ to $330^{\circ}$. The two most stable structures, with dihedral angles of $0^{\circ}$ (to give the major $S_{\mathrm{P}}$ diastereoisomer) and $180^{\circ}$ (to give the minor $S_{\mathrm{P}}$ diastereoisomer), were identified and calculated in greater detail (M06/LanL2DZ(Fe)\&6$31 \mathrm{G}(\mathrm{d}), \mathrm{SCRF}(\mathrm{PCM}$, solvent $=\mathrm{THF})$ ) at around $0^{\circ}$ and $180^{\circ}$. The conformation with the dihedral angle of $-6.6^{\circ}$ proved $4.0 \mathrm{kcal} . \mathrm{mol}^{-1}$ lower in energy than that of $180^{\circ}$. The calculation in gas-phase provided almost identical results; the conformation with the dihedral angle of $-6.0^{\circ}$ proved $4.6 \mathrm{kcal}$ $\mathrm{mol}^{-1}$ lower in energy than that of $190^{\circ} .{ }^{14}$ These calculated results are in accordance with the observed diastereoselectivity in the deproto-metalation of $\mathbf{6 j}$ (Scheme 6).
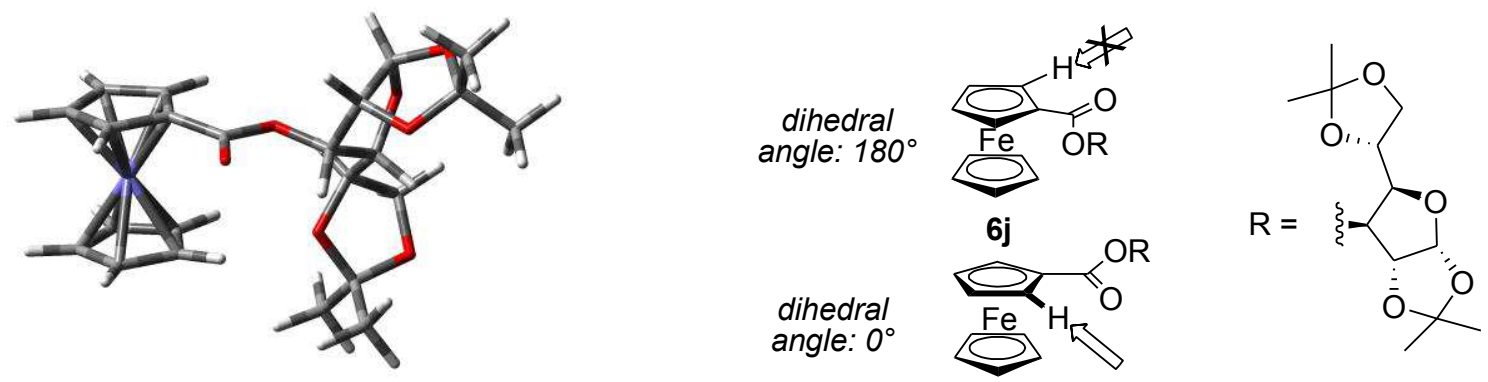

Scheme 6. Calculated most stable conformer (M06/LanL2DZ(Fe)\&6-31G(d)) of 6j in THF (SCRF calculation) and observed diastereoselectivity in its deproto-metalation.

In order to reach new kinds of ferrocene derivatives, coupling reactions were attempted using the iodoesters 7. Firstly, it was decided to attempt Ullmann-type coupling reactions on the iodoferrocenecarboxylate $\boldsymbol{R}_{\mathbf{P}} \mathbf{- 7} \mathbf{j}$, synthesized as described in Scheme 4, and isolated by chromatography over silica gel in about $75 \%$ yield. The reagent system comprising $\mathrm{NiCl}_{2}\left(\mathrm{PPh}_{3}\right)_{2}$, triphenylphosphine, zinc and sodium hydride, reported by Lin and Hong in $2001,{ }^{27}$ was attempted for this purpose, but only led to the deiodinated compound $\mathbf{6 j}$. In contrast, when methyl 2-iodoferrocenecarboxylate rac-7o, easily prepared by deprotonation-iodination, ${ }^{7 d}$ was involved in the reaction under the same conditions, the expected self-coupling products were obtained, and separated by chromatography over silica gel 
(Scheme 7). The meso derivative meso-10o and the racemic mixture rac-10'o were isolated in 53 and $15 \%$ yield, respectively, and both were unambiguously identified by X-ray diffraction (Figure 2).

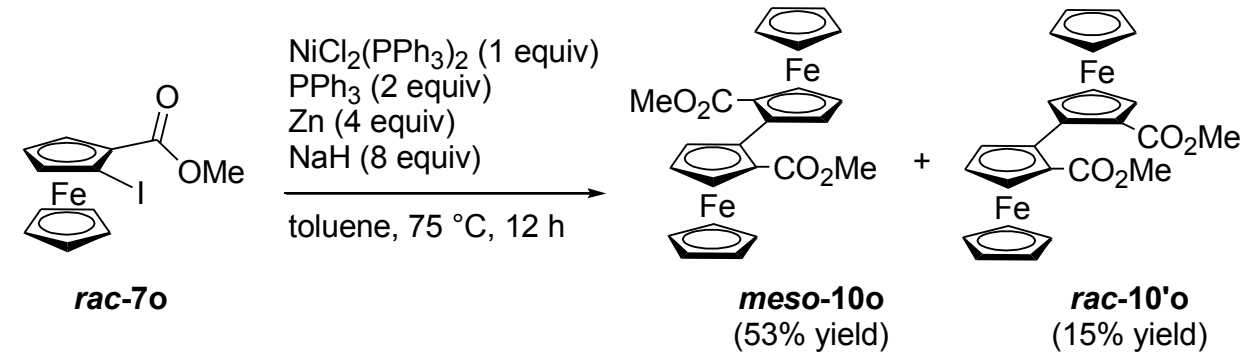

Scheme 7. Homocoupling of racemic methyl 2-iodoferrocenecarboxylate rac-7o.
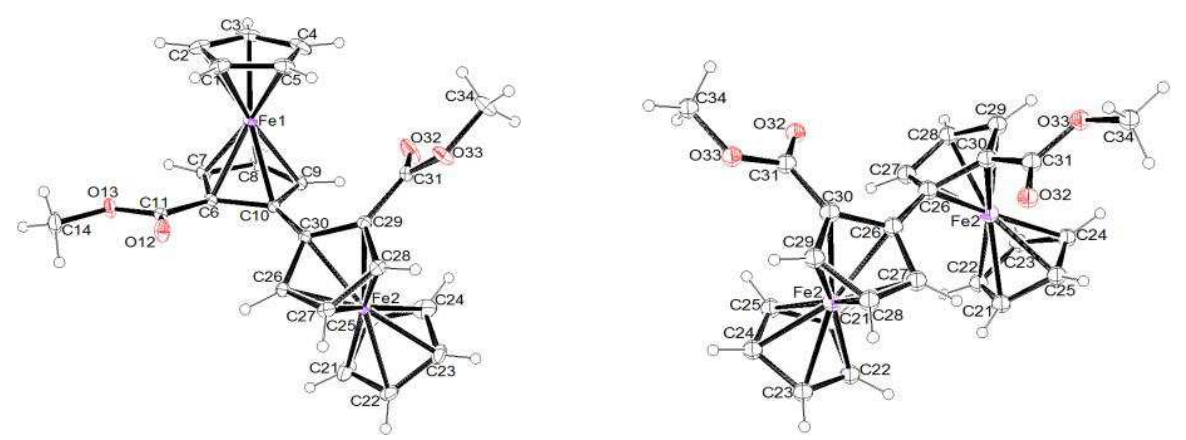

Figure 2. ORTEP diagram (30\% probability) of meso-10o and rac-10'0.

According to the result obtained from $\mathbf{r a c - 7 0}$, the reactions between opposite enantiomers $\left(\boldsymbol{R}_{\mathbf{P}} \mathbf{- 7} \mathbf{j}\right.$ and $S_{\mathbf{P}}-\mathbf{7 j}$, to afford meso-10o, 53\% yield) appears as more likely than the reactions between same enantiomers (to give rac-10'o, 15\% yield), because of ferrocene-ferrocene hindrance. When the methyl ester is replaced by the sugar-based group (substrate $\boldsymbol{R}_{\mathbf{P}} \mathbf{- 7} \mathbf{j}$ ), a meso compound cannot be obtained any more, and the formation of the $\boldsymbol{R}_{\mathbf{P}}, \boldsymbol{R}_{\mathbf{P}}$ coupled derivative becomes unlikely, probably for steric reasons.

Suzuki-type coupling reactions were finally performed from the 2-iodoferrocenecarboxylates $\boldsymbol{S}_{\mathbf{P}}-\mathbf{7} \mathbf{j}$ and $\boldsymbol{R}_{\mathbf{P}} \mathbf{- 7 n}$ (Scheme 8). Reaction of 4-methoxyphenylboronic acid with rac-7o was first carried out as a test reaction in the presence of cesium fluoride in order to avoid the use of basic reagents. ${ }^{28}$ The reaction proceeded at the reflux temperature of toluene using catalytic amounts of $\operatorname{Pd}(\mathrm{dba})_{2}$ and triphenylphosphine, affording the expected 4-methoxyphenyl derivative rac-110 in $97 \%$ yield. $\boldsymbol{S}_{\mathbf{P}^{-}} \mathbf{7} \mathbf{j}$ and $\boldsymbol{R}_{\mathbf{P}}-\mathbf{7 n}$ were similarly involved in the reaction, affording the coupled products $\boldsymbol{R}_{\mathbf{P}}-\mathbf{1 1} \mathbf{j}$ and $\boldsymbol{S}_{\mathbf{P}}-\mathbf{1 1} \mathbf{n}$, respectively. 

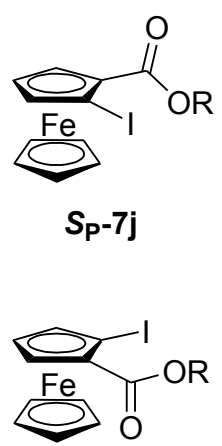

$R_{\mathrm{P}}-7 \mathrm{n}$

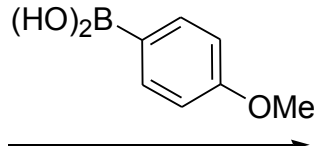

CsF (2 equiv) $\mathrm{Pd}(\mathrm{dba})_{2}$ (0.05 equiv) $\mathrm{PPh}_{3}$ (0.2 equiv) toluene, reflux, $12 \mathrm{~h}$

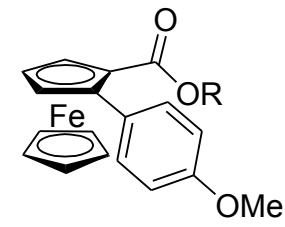

$\boldsymbol{R}_{\mathrm{P}-11 \mathrm{j}}$ (98\% yield)

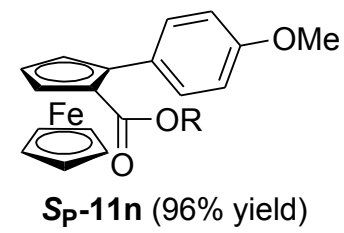

Scheme 8. Suzuki cross-couplings from 2-iodoferrocenecarboxylates $\boldsymbol{S}_{\mathrm{P}^{-}} \mathbf{7} \mathbf{j}$ and $\boldsymbol{R}_{\mathrm{P}^{-}} \mathbf{7} \mathbf{n}$.

\section{Conclusion}

In summary, several chiral esters were screened for their ability to induce diastereoselective deprotometalation reactions of ferrocenes using mixed lithium-cadmium and lithium-zinc bases. Due to the tolerance of these bimetallic combinations toward reactive functional groups, many substrates were functionalized at room temperature. Among the different groups tested, two proved impressive: the one present in ferrocenecarboxylate $\mathbf{6 j}$, generated from commercially available inexpensive diacetone-Dglucose (5j), allowing the synthesis of the iodo derivative $\mathbf{7 j}$ in either $74 \%$ yield and $90 \%$ de $\left(S_{\mathrm{P}}\right.$ diastereoisomer) using the TMEDA-free all TMP lithium-cadmium base or $85 \%$ yield and $91 \%$ de using a chiral lithium-zinc base (double asymmetric induction), and the one present in ferrocenecarboxylate $\mathbf{6 n}$, synthesized from 6-(tert-butoxycarbonylamino)-6-deoxy-3-O-methyl-1,2-Oisopropylidene- $\alpha$-D-glucofuranose (5n), leading to the iodo derivative $\boldsymbol{R}_{\mathbf{P}}-\mathbf{7 n}$ in $57 \%$ yield.

Through X-ray diffraction data of the ferrocene substrates or/and more accurate calculations of the most stable conformer, we could observe a direct link between the dihedral angle between the upper plane of the ferrocenyl moiety and the ester, and the planar chirality observed in the main diastereoisomer: a dihedral angle of about $180^{\circ}$ corresponds to major formation of the $R_{\mathrm{P}}$ diastereoisomer and a dihedral angle of about $0^{\circ}$ to major formation of the $S_{\mathrm{P}}$ diastereoisomer.

\section{Experimental Section}


4.1. General. All reactions were performed in Schlenk tubes under argon atmosphere. THF was distilled over sodium/benzophenone. Liquid chromatography separations were achieved on silica gel Merck-Geduran Si $60(63-200 \mu \mathrm{m})$. Nuclear magnetic resonance spectra were acquired using Bruker AC-300 (300 MHz and $75 \mathrm{MHz}$ for ${ }^{1} \mathrm{H}$ and ${ }^{13} \mathrm{C}$ respectively) or Avance 500 spectrometer $(500 \mathrm{MHz}$ and $125 \mathrm{MHz}$ for ${ }^{1} \mathrm{H}$ and ${ }^{13} \mathrm{C}$ respectively). ${ }^{1} \mathrm{H}$ chemical shifts $(\delta)$ are given in ppm relative to the solvent residual peak, and ${ }^{13} \mathrm{C}$ chemical shifts relative to the central peak of the solvent signal. High resolution mass spectra measurements were performed at the Centre Régional de Mesures Physiques de l'Ouest (CRMPO) in Rennes. 1,2:3,4-Di- $O$-isopropylidene- $\alpha$-D-galactopyranose (5e), 2,3:5,6-di- $O$ cyclohexylidene- $\alpha$-D-mannofuranose (5i), 1,2:5,6-di- $O$-isopropylidene- $\alpha$-D-glucofuranose (5j), 1,2:5,6di-O-cyclohexylidene- $\alpha$-D-glucofuranose (5k) and 1,2:5,6-di- $O$-isopropylidene- $\alpha$-D-allofuranose (5l) are commercially available. (2S,4S)-2-Ferrocenyl-4-(methoxymethyl)-1,4-dioxane $(\mathbf{2 d}){ }^{16 a}(R)-2-(4-$ methoxybenzyloxy)-1-propanol (5a), ${ }^{29}(R)-2-\left(\right.$ tert-butyldiphenylsilyloxy)-1-propanol $\quad(\mathbf{5 b}),^{30}(R)-N$ (tert-butoxycarbonyl)-4-(hydroxymethyl)-2,2-dimethyloxazolidine $\quad(\mathbf{5 c}),^{31} \quad$ 1,2-O-isopropylidene-3-Omethyl- $\alpha$-D-xylofuranose $\quad(\mathbf{5 d})^{32} \quad(1 R, 2 S)-N$-(tert-butoxycarbonyl)ephedrine $\quad(\mathbf{5 f})^{33}$ and 5 -O-(tertbutyldiphenylsilyl)-1,2-O-isopropylidene- $\alpha$-D-xylofuranose $(\mathbf{5 h})^{34}$ were prepared as previously described.

4.2. 1,2-O-Isopropylidene-3,5- $O$-(ferrocenylmethylene)- $\alpha$-D-xylofuranose (2c) was prepared from commercially available 1,2- $O$-isopropylidene- $\alpha$-D-xylofuranose (1c) by transacetalization of the known ferrocene dimethylacetal in chloroform using $p$-toluenesulfonic acid as catalyst. ${ }^{16 a}$ Purification by flash chromatography on silica gel (eluent: 100:0 to 92:8 heptane-EtOAc) afforded a pale yellow powder (yield: $60 \%$ for 2 steps): $\mathrm{mp} 163-164{ }^{\circ} \mathrm{C} ;{ }^{1} \mathrm{H} \mathrm{NMR}\left(300 \mathrm{MHz}, \mathrm{CDCl}_{3}\right) \delta 1.34(\mathrm{~s}, 3 \mathrm{H}), 1.52(\mathrm{~s}, 3 \mathrm{H})$, 4.05-4.21 (m, 9H), 4.30-4.43 (m, 4H), $4.62(\mathrm{~d}, 1 \mathrm{H}, J=3.7 \mathrm{~Hz}), 5.29(\mathrm{~s}, 1 \mathrm{H}), 6.05(\mathrm{~d}, 1 \mathrm{H}, J=3.7 \mathrm{~Hz})$; ${ }^{13} \mathrm{C} \mathrm{NMR}\left(75 \mathrm{MHz}, \mathrm{CDCl}_{3}\right) \delta 26.3,26.8,66.7,67.0,67.1,68.5,68.6,69.4(5 \mathrm{C}), 72.4,78.8,84.0,85.4$, 98.3, 105.8, 111.8; $[\alpha]_{\mathrm{D}}=-5.5\left(\mathrm{CHCl}_{3}, c=0.2,20{ }^{\circ} \mathrm{C}\right)$. Anal. Calcd for $\mathrm{C}_{9} \mathrm{H}_{22} \mathrm{FeO}_{5}$ (386.22): C, 59.09; 
H, 5.74. Found: C, 58.76; H, 5.62. The structure was identified unequivocally by X-ray structure analysis (CCDC 970485) from crystals obtained by slowly evaporating a 92:8 heptane-EtOAc solution.

\section{3. (2S,4R)-tert-Butyl 4-hydroxy-2-(tert-butyldiphenylsilyloxymethyl)-1-pyrrolidinecarboxylate}

(5g) was prepared following a described procedure, ${ }^{34}$ and was isolated as a white solid: $\mathrm{mp} 148{ }^{\circ} \mathrm{C} ;{ }^{1} \mathrm{H}$ NMR (300 MHz, $\left.\mathrm{CDCl}_{3}\right) \delta 1.03(\mathrm{~s}, 9 \mathrm{H}), 1.32$ and $1.47(\mathrm{~s}, 9 \mathrm{H}), 1.94-2.14(\mathrm{~m}, 1 \mathrm{H}), 2.29-2.37(\mathrm{~m}, 1 \mathrm{H})$, 3.42-3.77 and 3.97-4.10 (m, 5H), 4.50-4.57 (m, 1H), 7.34-7.42 (m, 6H), 7.60-7.64 (m, 4H); ${ }^{13} \mathrm{C}$ NMR $\left(75 \mathrm{MHz}, \mathrm{CDCl}_{3}\right) \delta 19.1,26.6,26.7$ (several C), 28.3, 28.4, 36.6, 37.2, 55.0, 55.1, 55.4, 55.5, 57.0, $57.1,57.2,63.7,63.8,64.8,69.4,70.1,79.2,79.3,79.4,127.6,129.5,133.2-133.4$ (4 signals), $135.4(2$ signals), 154.6-154.7 (4 signals); $[\alpha]_{\mathrm{D}}=-32\left(\mathrm{CHCl}_{3}, c=5.0,20{ }^{\circ} \mathrm{C}\right) ; \mathrm{HRMS}$ : calcd for $\mathrm{C}_{26} \mathrm{H}_{37} \mathrm{NNaO}_{4} \mathrm{Si}$ $\left[(\mathrm{M}+\mathrm{Na})^{+\bullet}\right]$ 478.2384, found 478.2385.

4.4. 5-(tert-Butoxycarbonylamino)-5-deoxy-1,2-O-isopropylidene- $\alpha$-D-xylofuranose (5m) and 6(tert-Butoxycarbonylamino)-6-deoxy-3-O-methyl-1,2-O-isopropylidene- $\alpha$-D-glucofuranose ${ }^{15}$ were prepared by adapting a described procedure. ${ }^{35}$ Their analyses were as described previously. ${ }^{15}$

4.5. General procedure for the reaction of ferrocenecarboxylic acid with chiral alcohols. A solution of ferrocenecarboxylic acid (0.93 g, $4.0 \mathrm{mmol})$, DCC (0.91 g, $4.4 \mathrm{mmol})$, the required chiral alcohol (4.0 mmol) and DMAP $(0.48 \mathrm{~g}, 4.4 \mathrm{mmol})$ in $\mathrm{CH}_{2} \mathrm{Cl}_{2}(40 \mathrm{~mL})$ was heated under reflux for 16 h. $N, N^{\prime}$-dicyclohexylurea was filtered off, and the filtrate was washed with water $(3 \times 40 \mathrm{~mL})$. After drying over anhydrous $\mathrm{Na}_{2} \mathrm{SO}_{4}$, the solvent was evaporated under reduced pressure, and the ester was isolated by purification by flash chromatography on silica gel.

4.5.1. (R)-2-(4-Methoxybenzyloxy)-1-propyl ferrocenecarboxylate (6a) was prepared from 5a (0.78 g) and was isolated (eluent: 93:7 heptane-EtOAc) as a red oil (yield: $45 \%):{ }^{1} \mathrm{H}$ NMR (300 MHz, $\left.\mathrm{CDCl}_{3}\right) \delta 1.29(\mathrm{~d}, 3 \mathrm{H}, J=6.4 \mathrm{~Hz}), 3.80(\mathrm{~s}, 3 \mathrm{H}), 3.81-3.87(\mathrm{~m}, 1 \mathrm{H}), 4.18$ and 4.31 (AB-part of an ABX system, $\left.2 \mathrm{H}, J_{A B}=11.5 \mathrm{~Hz}, J_{A X}=6.0 \mathrm{~Hz}, J_{B X}=4.2 \mathrm{~Hz}\right), 4.20(\mathrm{~s}, 3 \mathrm{H}), 4.40(\mathrm{t}, 2 \mathrm{H}, J=2.0 \mathrm{~Hz}), 4.58$ and $4.62\left(\mathrm{AB}, 2 \mathrm{H}, J_{A B}=11.5 \mathrm{~Hz}\right), 4.81-4.84(\mathrm{~m}, 2 \mathrm{H}), 6.88(\mathrm{~d}, 2 \mathrm{H}, J=8.7 \mathrm{~Hz}), 7.32(\mathrm{~d}, 2 \mathrm{H}, J=8.7 \mathrm{~Hz}) ;{ }^{13} \mathrm{C}$ $\operatorname{NMR}\left(75 \mathrm{MHz}, \mathrm{CDCl}_{3}\right) \delta 17.4,55.4,67.1,69.9$ (5C), 70.3 (2C), 70.9, 71.1, $71.4(2 \mathrm{C}), 72.6,113.9$ 
(2C), $129.4(2 \mathrm{C}), 130.7,159.2,171.7 ;[\alpha]_{\mathrm{D}}=+0.83\left(\mathrm{CH}_{2} \mathrm{Cl}_{2}, c=1.9,20{ }^{\circ} \mathrm{C}\right)$. Anal. Calcd for $\mathrm{C}_{22} \mathrm{H}_{24} \mathrm{FeO}_{4}$ (408.27): C, 64.72; H, 5.93. Found: C, 64.45; H, 5.99.

4.5.2. (R)-2-(tert-Butyldiphenylsilyloxy)-1-propyl ferrocenecarboxylate (6b) was prepared from 5b (1.3 g) and was isolated (eluent: 93:7 heptane-EtOAc) as an orange oil (yield: 53\%): ${ }^{1} \mathrm{H}$ NMR (500 $\left.\mathrm{MHz}, \mathrm{CDCl}_{3}\right) \delta 1.09(\mathrm{~s}, 9 \mathrm{H}), 1.17(\mathrm{~d}, 3 \mathrm{H}, J=6.0 \mathrm{~Hz}), 4.12(\mathrm{~m}, 3 \mathrm{H}), 4.16(\mathrm{~s}, 5 \mathrm{H}), 4.37(\mathrm{t}, 2 \mathrm{H}, J=1.9$ $\mathrm{Hz}), 4.8(\mathrm{br} \mathrm{d}, 2 \mathrm{H}, J=9.0 \mathrm{~Hz}), 7.35-7.43(\mathrm{~m}, 6 \mathrm{H}), 7.72(\mathrm{~m}, 4 \mathrm{H}) ;{ }^{13} \mathrm{C} \mathrm{NMR}\left(125 \mathrm{MHz}, \mathrm{CDCl}_{3}\right) \delta 19.4$, 20.7, 27.1 (3C), 67.8, 69.3, 69.9 (5C), 70.3, 70.4, 70.7, 71.4 (2C), 127.7 (2C), 127.8 (2C), 129.8, 129.9, 134.1, 134.4, $135.9(2 \mathrm{C}), 136.0(2 \mathrm{C}), 171.7 ;[\alpha]_{\mathrm{D}}=-5.7\left(\mathrm{CH}_{2} \mathrm{Cl}_{2}, c=0.35,20{ }^{\circ} \mathrm{C}\right)$. Anal. Calcd for $\mathrm{C}_{30} \mathrm{H}_{34} \mathrm{FeO}_{3} \mathrm{Si}$ (526.52): C, 68.43; H, 6.51. Found: C, 68.77; H, 6.79.

4.5.3. (S)-[N-(tert-Butoxycarbonyl)-2,2-dimethyl-4-oxazolidyl]methyl ferrocenecarboxylate (6c) was prepared from $\mathbf{5 c}(0.93 \mathrm{~g})$ and was isolated (eluent: 88:12 heptane-EtOAc) as a red powder (yield: 76\%): mp $70{ }^{\circ} \mathrm{C} ;{ }^{1} \mathrm{H}$ NMR (500 MHz, $\left.340 \mathrm{~K}, \mathrm{C}_{6} \mathrm{D}_{6}\right) \delta 1.44(\mathrm{~s}, 9 \mathrm{H}), 1.51(\mathrm{~s}, 3 \mathrm{H}), 1.69(\mathrm{~s}, 3 \mathrm{H}), 3.74(\mathrm{dd}$, $1 \mathrm{H}, J=6.5,8.8 \mathrm{~Hz}), 3.89$ (d, 1H, $J=8.8 \mathrm{~Hz}), 4.00(\mathrm{~m}, 1 \mathrm{H}), 4.02(\mathrm{~s}, 5 \mathrm{H}), 4.09$ (s, 2H), $4.20(\mathrm{br} \mathrm{m}, 1 \mathrm{H})$, $4.56(\mathrm{dd}, 1 \mathrm{H}, J=3.2,10.4 \mathrm{~Hz}), 4.81(\mathrm{~d}, 2 \mathrm{H}, J=6.7 \mathrm{~Hz}) ;{ }^{13} \mathrm{C}$ NMR $\left(125 \mathrm{MHz}, 340 \mathrm{~K}, \mathrm{C}_{6} \mathrm{D}_{6}\right) \delta 23.5$, $27.3,28.6(3 \mathrm{C}), 56.7,63.6,65.7,70.1(5 \mathrm{C}), 70.7,70.8,71.4(2 \mathrm{C}), 72.2,80.0,94.4,152.1,170.7 ;[\alpha]_{\mathrm{D}}=$ $-16\left(\mathrm{CH}_{2} \mathrm{Cl}_{2}, c=1.0,20{ }^{\circ} \mathrm{C}\right)$. Anal. Calcd for $\mathrm{C}_{22} \mathrm{H}_{29} \mathrm{FeNO}_{5}$ (443.31): C, 59.60; H, 6.59; N, 3.16 . Found: $\mathrm{C}, 59.30 ; \mathrm{H}, 6.54 ; \mathrm{N}, 3.11$. The structure was identified unequivocally by X-ray structure analysis (CCDC 970486) from crystals obtained by slowly evaporating a 2:8 EtOAc-heptane solution.

4.5.4. 6- $O$-(Ferrocenecarbonyl)-1,2- $O$-isopropylidene-3- $O$-methyl- $\alpha$-D-xylofuranose $(6 \mathrm{~d})$ was prepared as described previously. ${ }^{15}$ Its structure was identified unequivocally by X-ray structure analysis (CCDC 798861) from crystals obtained by slowly evaporating a 2:8 $\mathrm{CH}_{2} \mathrm{Cl}_{2}$-pentane solution.

4.5.5. 6-O-(Ferrocenecarbonyl)-1,2:3,4-di- $O$-isopropylidene- $\alpha$-D-galactopyranose (6e) was prepared as described previously. ${ }^{15}$ Its structure was identified unequivocally by X-ray structure analysis (CCDC 798860) from crystals obtained by slowly evaporating a $\mathrm{CH}_{2} \mathrm{Cl}_{2}$ solution. 
ferrocenecarboxylate (6f) was prepared from $\mathbf{5 f}(1.1 \mathrm{~g})$ and was isolated (eluent: 92:8 heptane-EtOAc) as a red oil (yield: 38\%): ${ }^{1} \mathrm{H}$ NMR (500 MHz, $\left.340 \mathrm{~K}, \mathrm{C}_{6} \mathrm{D}_{6}\right) \delta 1.22(\mathrm{~d}, 3 \mathrm{H}, J=6.9 \mathrm{~Hz}), 1.36(\mathrm{~s}, 9 \mathrm{H})$, 2.59 (br s, 3H), 3.89 (s, 5H), 4.08 (s, 2H), 4.74 (br s, 1H), 4.77 (br s, 1H), 4.83 (br s, 1H), 6.22 (d, 1H, J $=8.1 \mathrm{~Hz}), 7.07(\mathrm{t}, 1 \mathrm{H}, J=7.3 \mathrm{~Hz}), 7.16(\mathrm{~m}, 2 \mathrm{H}), 7.52(\mathrm{~d}, 2 \mathrm{H}, J=7.4 \mathrm{~Hz}) ;{ }^{13} \mathrm{C} \mathrm{NMR}(125 \mathrm{MHz}, 340 \mathrm{~K}$, $\left.\mathrm{C}_{6} \mathrm{D}_{6}\right) \delta 14.4,28.5(3 \mathrm{C}), 30.1,55.2,70.0(5 \mathrm{C}), 70.5,70.7,71.3,71.4,72.4,77.4,79.2,127.8-128.4$ (5C), 139.8, 155.3, 169.9; $[\alpha]_{\mathrm{D}}=+47.6\left(\mathrm{CH}_{2} \mathrm{Cl}_{2}, c=2.5,20{ }^{\circ} \mathrm{C}\right)$. Anal. Calcd for $\mathrm{C}_{26} \mathrm{H}_{31} \mathrm{FeNO}_{4}$ (477.37): C, 65.42; H, 6.55; N, 2.93. Found: C, 65.34; H, 6.63; N, 3.03.

4.5.7 (2S,4R)-1-tert-Butoxycarbonyl-2-(tert-butyldiphenylsilyloxymethyl)-4-pyrrolidyl ferrocenecarboxylate $(6 \mathrm{~g})$ was prepared from $\mathbf{5 g}(1.8 \mathrm{~g})$ using DCC (1.2 g, $6.0 \mathrm{mmol})$ and DMAP (0.65 g, $6.0 \mathrm{mmol})$ in $\mathrm{CH}_{2} \mathrm{Cl}_{2}(20 \mathrm{~mL})$, and was isolated (eluent: 93:7 heptane-EtOAc) as an orange gum (yield: 83\%): ${ }^{1} \mathrm{H}$ NMR $\left(300 \mathrm{MHz}, \mathrm{CDCl}_{3}\right) \delta 1.06(\mathrm{~s}, 9 \mathrm{H}), 1.36$ and $1.48(\mathrm{~s}, 9 \mathrm{H}), 2.17-2.33(\mathrm{~m}$, 1H), 2.44-2.56 (m, 1H), 3.63-3.90 (m, 4H), 4.05-4.23 (m, 1H), $4.20(\mathrm{~s}, 5 \mathrm{H}), 4.40$ (br s, 2H), 4.77-4.80 $(\mathrm{m}, 2 \mathrm{H}), 5.47-5.51(\mathrm{~m}, 1 \mathrm{H}), 7.36-7.43(\mathrm{~m}, 6 \mathrm{H}), 7.63-7.68(\mathrm{~m}, 4 \mathrm{H}) ;{ }^{13} \mathrm{C} \mathrm{NMR}\left(75 \mathrm{MHz}, \mathrm{CDCl}_{3}\right)$ mixture of conformers $\delta 19.1,19.2,19.2,26.8,28.4,28.5,33.7,35.0,52.5,53.3,57.3,57.3,57.3,63.8$, 64.9, 69.7 (several C), 69.9, 70.1, 70.2, 70.7, 70.9, 71.3, 71.3, 71.4, 72.3, 72.3, 72.9, 76.5, 79.6, 127.6, $127.7,127.7,129.6,129.6,129.7,133.2,135.5,154.2,154.3,171.2,171.4 ;[\alpha]_{\mathrm{D}}=-36.5\left(\mathrm{CHCl}_{3}, c=\right.$ 0.41, $\left.20^{\circ} \mathrm{C}\right)$; HRMS: calcd for $\mathrm{C}_{37} \mathrm{H}_{45}{ }^{56} \mathrm{FeNNaO}_{5} \mathrm{Si}\left[(\mathrm{M}+\mathrm{Na})^{+\bullet}\right]$ 690.2309, found 690.2308.

\subsubsection{3-O-(Ferrocenecarbonyl)-5-O-(tert-butyldiphenylsilyl)-1,2-O-isopropylidene- $\alpha$-D-}

xylofuranose $(6 \mathrm{~h})$ and 1- $O$-(ferrocenecarbonyl)-2,3:5,6-di- $O$-cyclohexylidene- $\alpha$-D-mannofuranose (6i) were prepared as described previously. ${ }^{15}$ The structure of $6 \mathbf{i}$ was identified unequivocally by X-ray structure analysis (CCDC 798862) from crystals obtained by slowly evaporating a 7:3 hexane- $\mathrm{CH}_{2} \mathrm{Cl}_{2}$ solution. 
4.5.9. 3-O-(Ferrocenecarbonyl)-1,2:5,6-di- $O$-isopropylidene- $\alpha$-D-glucofuranose (6j) was prepared as described previously. ${ }^{15}$ Its structure was identified unequivocally by X-ray structure analysis (CCDC 798863) from crystals obtained by slowly evaporating a 1:1 pentane- $\mathrm{CH}_{2} \mathrm{Cl}_{2}$ solution.

\subsubsection{3- $O$-(Ferrocenecarbonyl)-1,2:5,6-di- $O$-cyclohexylidene- $\alpha$-D-glucofuranose ${ }^{15}$ (6k) was} prepared as described previously. ${ }^{15}$ Its structure was identified unequivocally by X-ray structure analysis (CCDC 970487) from crystals obtained by slowly evaporating a 7:3 hexane- $\mathrm{CH}_{2} \mathrm{Cl}_{2}$ solution.

4.5.11. 3-O-(Ferrocenecarbonyl)-1,2:5,6-di- $O$-isopropylidene- $\alpha$-D-allofuranose (6I) was prepared as described previously. ${ }^{15}$ Its structure was identified unequivocally by X-ray structure analysis (CCDC 798864) from crystals obtained by slowly evaporating a 7:3 hexane- $\mathrm{CH}_{2} \mathrm{Cl}_{2}$ solution.

4.5.12. 5-(tert-Butoxycarbonylamino)-5-deoxy-3- $O$-(ferrocenecarbonyl)-1,2- $O$-isopropylidene- $\alpha$ D-xylofuranose (6m) and 6-(tert-butoxycarbonylamino)-6-deoxy-5-O-(ferrocenecarbonyl)-1,2-Oisopropylidene-3-O -methyl- $\boldsymbol{\alpha}$-D-glucofuranose (6n) were prepared as described previously. ${ }^{15,14}$

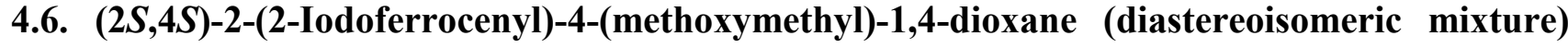

(3d). To a stirred cooled $\left(0^{\circ} \mathrm{C}\right)$ solution of 2,2,6,6-tetramethylpiperidine $(0.68 \mathrm{~mL}, 4.0 \mathrm{mmol})$ in $\mathrm{THF}$ (5 mL) were successively added BuLi (1.6 M hexanes solution, $4.0 \mathrm{mmol})$ and, $5 \mathrm{~min}$ later, $\mathrm{ZnCl}_{2} \cdot \mathrm{TMEDA}^{7 \mathrm{e}}(0.51 \mathrm{~g}, 2.0 \mathrm{mmol})$. The mixture was stirred for $10 \mathrm{~min}$ at $0{ }^{\circ} \mathrm{C}$ before introduction of 2d $(0.63 \mathrm{~g}, 2.0 \mathrm{mmol})$. After $10 \mathrm{~min}$ at room temperature, a cooled $\left(-30^{\circ} \mathrm{C}\right)$ solution prepared in $\mathrm{THF}$ (5 mL) from 2,2,6,6-tetramethylpiperidine $(0.68 \mathrm{~mL}, 4.0 \mathrm{mmol})$ and BuLi (1.6 $\mathrm{M}$ hexanes solution, 4.0 mmol) was added, and the resulting mixture was stirred for $2 \mathrm{~h}$ at $-30{ }^{\circ} \mathrm{C}$ before a solution of $\mathrm{I}_{2}(2.0 \mathrm{~g}$, $8.0 \mathrm{mmol})$ in THF (5 mL) was added. The mixture was stirred overnight before addition of an aq saturated solution of $\mathrm{Na}_{2} \mathrm{~S}_{2} \mathrm{O}_{3}(10 \mathrm{~mL})$ and extraction with EtOAc $(3 \times 20 \mathrm{~mL})$. After drying over anhydrous $\mathrm{Na}_{2} \mathrm{SO}_{4}$, the solvent was evaporated under reduced pressure, and the iodide $\mathbf{3 d}$ was isolated by purification by flash chromatography on silica gel (eluent: 9:1 heptane-EtOAc) in an estimated 45\% yield. A $79 \%$ de was determined by NMR. The minor isomer was identified as $\left(2 S, 4 S, R_{\mathrm{P}}\right)-2-(2-$ iodoferrocenyl)-4-(methoxymethyl)-1,4-dioxane $\left(\boldsymbol{R}_{\mathbf{P}-3 \mathbf{d}}\right)$ by comparison with reported ${ }^{13} \mathrm{C}$ NMR data in 
$\mathrm{C}_{6} \mathrm{D}_{6}:{ }^{16 \mathrm{r}}{ }^{13} \mathrm{C}$ NMR $\left(75 \mathrm{MHz}, \mathrm{C}_{6} \mathrm{D}_{6}\right) \delta 28.0\left(\mathrm{CH}_{2}\right), 42.4(\mathrm{C}), 59.1\left(\mathrm{CH}_{3}\right), 66.8\left(\mathrm{CH}_{2}\right), 67.0(\mathrm{CH}), 69.0$ $(\mathrm{CH}), 72.3(5 \mathrm{CH}), 75.0(\mathrm{CH}), 75.9\left(\mathrm{CH}_{2}\right), 76.4(\mathrm{CH}), 87.3(\mathrm{C}), 100.9(\mathrm{CH}) ;{ }^{13} \mathrm{C}$ NMR $(75 \mathrm{MHz}$, $\left.\mathrm{CDCl}_{3}\right) \delta 27.9\left(\mathrm{CH}_{2}\right), 41.7(\mathrm{C}), 59.6\left(\mathrm{CH}_{3}\right), 66.3(\mathrm{CH}), 67.0\left(\mathrm{CH}_{2}\right), 68.9(\mathrm{CH}), 72.0(5 \mathrm{CH}), 74.8(\mathrm{CH})$, $75.7\left(\mathrm{CH}_{2}\right), 76.4(\mathrm{CH}), 86.4(\mathrm{C}), 100.7(\mathrm{CH})$. The major isomer proved to be $\left(2 S, 4 S, S_{\mathrm{P}}\right)-2-(2-$ iodoferrocenyl)-4-(methoxymethyl)-1,4-dioxane $\left(\boldsymbol{S}_{\mathrm{P}}-\mathbf{3 d}\right):{ }^{13} \mathrm{C}$ NMR $\left(75 \mathrm{MHz}, \mathrm{C}_{6} \mathrm{D}_{6}\right) \delta 28.5\left(\mathrm{CH}_{2}\right), 42.1$ (C), $59.1\left(\mathrm{CH}_{3}\right), 66.9(\mathrm{CH}), 66.9\left(\mathrm{CH}_{2}\right), 68.9(\mathrm{CH}), 72.2(5 \mathrm{CH}), 75.1(\mathrm{CH}), 75.6\left(\mathrm{CH}_{2}\right), 76.5(\mathrm{CH}), 87.5$ (C), $101.0(\mathrm{CH}) ;{ }^{13} \mathrm{C}$ NMR $\left(75 \mathrm{MHz}, \mathrm{CDCl}_{3}\right) \delta 28.1\left(\mathrm{CH}_{2}\right), 41.6(\mathrm{C}), 59.4\left(\mathrm{CH}_{3}\right), 66.3(\mathrm{CH}), 67.1$ $\left(\mathrm{CH}_{2}\right), 68.8(\mathrm{CH}), 71.9(5 \mathrm{CH}), 75.0(\mathrm{CH}), 75.4\left(\mathrm{CH}_{2}\right), 76.3(\mathrm{CH}), 86.1(\mathrm{C}), 101.0(\mathrm{CH})$.

4.7. (a) General procedure for the deprotonation using the lithium-cadmium base prepared from $\mathrm{CdCl}_{2} \cdot$ TMEDA (1 equiv) and Li(TMP) (3 equiv) in THF followed by trapping using $\mathrm{I}_{2}$. To a stirred cooled $\left(0^{\circ} \mathrm{C}\right)$ solution of 2,2,6,6-tetramethylpiperidine $(1.1 \mathrm{~mL}, 6.0 \mathrm{mmol})$ in THF $(5 \mathrm{~mL})$ were successively added BuLi (1.6 M hexanes solution, $6.0 \mathrm{mmol})$ and, $5 \mathrm{~min}$ later, $\mathrm{CdCl}_{2} \cdot \mathrm{TMEDA}^{36}(0.60$ g, $2.0 \mathrm{mmol})$. The mixture was stirred for $10 \mathrm{~min}$ at $0{ }^{\circ} \mathrm{C}$ before introduction of the required substrate (2.0 mmol). After $2 \mathrm{~h}$ at room temperature, a solution of $\mathrm{I}_{2}(1.5 \mathrm{~g}, 6.0 \mathrm{mmol})$ in THF $(5 \mathrm{~mL})$ was added. The mixture was stirred overnight before addition of an aq saturated solution of $\mathrm{Na}_{2} \mathrm{~S}_{2} \mathrm{O}_{3}(10 \mathrm{~mL})$ and extraction with EtOAc $(3 \times 20 \mathrm{~mL})$. After drying over anhydrous $\mathrm{Na}_{2} \mathrm{SO}_{4}$, the solvent was evaporated under reduced pressure, and the iodide was isolated by purification by flash chromatography on silica gel. (b) General procedure for the conversion of 2-iodoferrocenecarboxylates 7 to 2 iodoferrocenemethanol (9). ${ }^{21}$ The required diastereoisomeric mixture of iodoferrocenecarboxylates 7 $(0.30 \mathrm{mmol})$ was dissolved in THF $(3 \mathrm{~mL})$, and a 1.0 M DIBAL-H solution in heptane (1.2 mL, 1.2 mmol) was added dropwise at $0{ }^{\circ} \mathrm{C}$. The mixture was stirred at this temperature for $1 \mathrm{~h}$ before quenching by addition of $\mathrm{MeOH}(0.5 \mathrm{~mL})$, dilution with $\mathrm{Et}_{2} \mathrm{O}(10 \mathrm{~mL})$, and addition of an aqueous saturated solution of sodium and potassium tartrate $(10 \mathrm{~mL})$ at $0{ }^{\circ} \mathrm{C}$. After stirring for $30 \mathrm{~min}$ at room temperature, extraction with $\mathrm{Et}_{2} \mathrm{O}$ and drying over anhydrous $\mathrm{Na}_{2} \mathrm{SO}_{4}$, the solvent was evaporated under reduced pressure, and 2-iodoferrocenemethanol (9) was isolated as orange crystals by purification 
by flash chromatography on silica gel (eluent: 88:12 heptane-EtOAc). HPLC analysis on a chiral stationary phase (AS-H column, eluent: 9:1 hexane-isopropanol, $1 \mathrm{~mL} / \mathrm{min}, \lambda=252 \mathrm{~nm}$ ) gave two well separated peaks for the two enantiomers of 2-iodoferrocenemethanol $\left(\boldsymbol{R}_{\mathrm{P}} \mathbf{- 9}, 12.5 \mathrm{~min}\right.$, and $\boldsymbol{S}_{\mathrm{P}-\mathbf{9}}, 22.2$ $\min )$.

4.7.1. $(2 S, 4 S)-2-(2,5-D i i o d o f e r r o c e n y l)-4-(m e t h o x y m e t h y l)-1,4-d i o x a n e ~(4 d)$ was prepared from 2d (0.63 g) using 4.7. (a) and was isolated (eluent: 85:15 heptane-EtOAc) as an orange oil (yield: 79\%): ${ }^{1} \mathrm{H}$ NMR $\left(300 \mathrm{MHz}, \mathrm{CDCl}_{3}\right) \delta 1.50(\mathrm{ddd}, 1 \mathrm{H}, J=13.0,3.8$ and $2.3 \mathrm{~Hz}), 1.86(\mathrm{ddd}, 1 \mathrm{H}, J=16.6,12.5$ and $5.0 \mathrm{~Hz}), 3.45(\mathrm{~s}, 3 \mathrm{H}), 3.48(\mathrm{dd}, 1 \mathrm{H}, J=10.2$ and $4.8 \mathrm{~Hz}), 3.63(\mathrm{dd}, 1 \mathrm{H}, J=10.2$ and $6.4 \mathrm{~Hz}), 3.94$ (td, $1 \mathrm{H}, J=12.1$ and $2.5 \mathrm{~Hz}), 4.08$ (dddd, $1 \mathrm{H}, J=11.2,6.7,4.6$ and $2.4 \mathrm{~Hz}), 4.22(\mathrm{~s}, 5 \mathrm{H}), 4.29$ (ddd, $1 \mathrm{H}, J=11.3,4.9$ and $1.2 \mathrm{~Hz}), 4.49(\mathrm{~d}, 1 \mathrm{H}, J=2.4 \mathrm{~Hz}), 4.52(\mathrm{~d}, 1 \mathrm{H}, J=2.4 \mathrm{~Hz}), 5.45(\mathrm{~s}, 1 \mathrm{H}) ;{ }^{13} \mathrm{C} \mathrm{NMR}$ $\left(75 \mathrm{MHz}, \mathrm{CDCl}_{3}\right) \delta 28.0\left(\mathrm{CH}_{2}\right), 39.0(\mathrm{C}), 40.7(\mathrm{C}), 59.6\left(\mathrm{CH}_{3}\right), 67.2\left(\mathrm{CH}_{2}\right), 75.1(5 \mathrm{CH}), 75.8\left(\mathrm{CH}_{2}\right)$, $76.4(\mathrm{CH}), 76.6(\mathrm{CH}), 77.1(\mathrm{CH}), 85.1(\mathrm{C}), 100.8(\mathrm{CH})$. Anal. Calcd for $\mathrm{C}_{16} \mathrm{H}_{18} \mathrm{FeI}_{2} \mathrm{O}_{3}(567.97)$ : C, 33.83; H, 3.19. Found: C, 33.70; H, 3.41.

4.7.2. (R)-2-(4-Methoxybenzyloxy)-1-propyl 2,5-diiodoferrocenecarboxylate (8a) was prepared from 6a (0.82 g) using 4.7. (a) and was isolated (eluent: 94:6 heptane-EtOAc) as a red oil (yield: 29\%): ${ }^{1} \mathrm{H}$ NMR $\left(300 \mathrm{MHz}, \mathrm{CDCl}_{3}\right) \delta 1.38(\mathrm{~d}, 3 \mathrm{H}, J=6.3 \mathrm{~Hz}), 3.78(\mathrm{~s}, 3 \mathrm{H}), 3.96($ hex, $1 \mathrm{H}, J=5.6 \mathrm{~Hz}), 4.24$ $(\mathrm{s}, 5 \mathrm{H}), 4.32$ and 4.41 (AB-part of an ABX system, $2 \mathrm{H}, J_{A B}=11.4 \mathrm{~Hz}, J_{A X}=5.5 \mathrm{~Hz}, J_{B X}=4.6 \mathrm{~Hz}$ ), 4.58 and $4.64\left(\mathrm{AB}, 2 \mathrm{H}, J_{A B}=11.4 \mathrm{~Hz}\right), 4.76(\mathrm{~s}, 2 \mathrm{H}), 6.86(\mathrm{~d}, 2 \mathrm{H}, J=8.6 \mathrm{~Hz}), 7.33(\mathrm{~d}, 2 \mathrm{H}, J=8.6 \mathrm{~Hz}) ;{ }^{13} \mathrm{C}$ NMR (75 MHz, $\left.\mathrm{CDCl}_{3}\right) \delta 17.9,39.0$ (2C), 55.4, 67.5, 70.8, 72.6, 73.3, 75.9 (5C), 80.6 (2C), 113.9 (2C), $129.5(2 \mathrm{C}), 130.6,159.2,168.8 ;[\alpha]_{\mathrm{D}}=-9.7\left(\mathrm{CH}_{2} \mathrm{Cl}_{2}, c=1.5,20{ }^{\circ} \mathrm{C}\right)$. Anal. Calcd for $\mathrm{C}_{22} \mathrm{H}_{22} \mathrm{FeI}_{2} \mathrm{O}_{4}$ (660.06): C, 40.03; H, 3.36. Found: C, 40.07; H, 3.42.

4.7.3. (R)-2-(tert-Butyldiphenylsilyloxy)-1-propyl 2,5-diiodoferrocenecarboxylate (8b) was prepared from 6b (1.1 g) using 4.7. (a) and was isolated (eluent: 96:4 pentane-Et $2 \mathrm{O}$ ) as a red oil (yield: $68 \%$ ). The analyses were as described previously. ${ }^{7 \mathrm{~d}}$ 
iodoferrocenecarboxylate (diastereoisomeric mixture) (7c) was prepared from $6 \mathbf{c}(0.89 \mathrm{~g})$ using 4.7. (a) but could not be separated from the starting material (estimated yield: 18\%), and the mixture was treated with DIBAL-H according to 4.7. (b) to afford 2-iodoferrocenemethanol (9) in 98\% yield and $14 \%$ ee $\left(R_{\mathrm{P}}\right)$.

\subsection{5.}

3-O-(2-Iodoferrocenecarbonyl)-1,2:5,6-di-O-cyclohexylidene- $\alpha$-D-glucofuranose

(diastereoisomeric mixture) (7k) was prepared from 6k (1.1 g) using 4.7. (a) and was isolated (eluent: 95:5 heptane-EtOAc) as an orange solid (93\% yield). A 54\% de was determined by NMR. The analyses were as described previously. ${ }^{15}$ Treatment with DIBAL-H according to 4.7. (b) afforded 2iodoferrocenemethanol (9) in 94\% yield and 58\% ee $\left(S_{\mathrm{P}}\right)$.

4.7.6. 3-O-(2-Iodoferrocenecarbonyl)-1,2:5,6-di- $O$-isopropylidene- $\alpha$-D-allofuranose

(diastereoisomeric mixture) $^{15,14}$ (7l) was prepared from 61 (0.94 g) using 4.7. (a) but could not be separated from the starting material (estimated yield: $82 \%$ ). It was identified by HRMS: calcd for $\mathrm{C}_{23} \mathrm{H}_{27}{ }^{56} \mathrm{FeINaO}_{7}\left[(\mathrm{M}+\mathrm{Na})^{+\bullet}\right]$ 621.0043, found 621.0043. The mixture was treated with DIBAL-H according to 4.7. (b) to afford 2-iodoferrocenemethanol (9) in 95\% yield and $32 \%$ ee $\left(S_{\mathrm{P}}\right)$.

4.7.7. 6-(tert-Butoxycarbonylamino)-6-deoxy-5-O-(2,5-diiodoferrocenecarbonyl)-1,2-Oisopropylidene-3- $\boldsymbol{O}$-methyl- $\boldsymbol{\alpha}$-D-glucofuranose (8n) was prepared from $6 \mathbf{n}(1.1 \mathrm{~g})$ using 4.7. (a) and was isolated (eluent: 3:7 heptane-EtOAc) as a yellow liquid (yield: $37 \%):{ }^{1} \mathrm{H} \mathrm{NMR}\left(300 \mathrm{MHz}, \mathrm{CDCl}_{3}\right)$ $\delta 1.32(\mathrm{~s}, 3 \mathrm{H}), 1.42(\mathrm{~s}, 9 \mathrm{H}), 1.50(\mathrm{~s}, 3 \mathrm{H}), 3.41(\mathrm{~s}, 3 \mathrm{H}), 3.53-3.62(\mathrm{~m}, 1 \mathrm{H}), 3.79-3.87(\mathrm{~m}, 1 \mathrm{H}), 3.93(\mathrm{~d}$, $1 \mathrm{H}, J=3.2 \mathrm{~Hz}), 4.27(\mathrm{~s}, 5 \mathrm{H}), 4.43(\mathrm{dd}, 1 \mathrm{H}, J=6.7,3.1 \mathrm{~Hz}), 4.58(\mathrm{~d}, 1 \mathrm{H}, J=5.2 \mathrm{~Hz}), 4.78(\mathrm{~s}, 2 \mathrm{H}), 5.11$ $(\mathrm{t}, 1 \mathrm{H}, J=5.2 \mathrm{~Hz}), 5.43-5.49(\mathrm{~m}, 1 \mathrm{H}), 5.93(\mathrm{~d}, 1 \mathrm{H}, J=3.7 \mathrm{~Hz}) ;{ }^{13} \mathrm{C} \mathrm{NMR}\left(75 \mathrm{MHz}, \mathrm{CDCl}_{3}\right) \delta 26.4$, 27.1, $28.6(3 \mathrm{C}), 41.9,58.2,70.6(2 \mathrm{C}), 76.1$ (5C), 79.4, 79.9, 80.7, 80.8, 80.9, 81.4, 83.9, 105.3 (2C), 112.0, 155.9, 168.0; $[\alpha]_{\mathrm{D}}=-10\left(\mathrm{CH}_{2} \mathrm{Cl}_{2}, c=1.1,20{ }^{\circ} \mathrm{C}\right)$. Anal. Calcd for $\mathrm{C}_{26} \mathrm{H}_{33} \mathrm{FeI}_{2} \mathrm{NO}_{8}(797.20)$ : $\mathrm{C}$, 39.17; H, 4.17; N, 1.76. Found: C, 39.52; H, 4.45; N, 1.67. 
4.8. General procedure for the deprotonation using the lithium-cadmium base prepared from

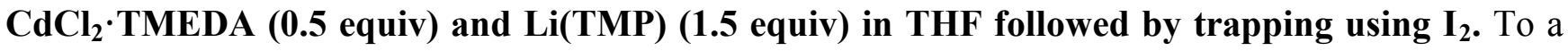
stirred cooled $\left(0^{\circ} \mathrm{C}\right)$ solution of 2,2,6,6-tetramethylpiperidine $(1.1 \mathrm{~mL}, 6.0 \mathrm{mmol})$ in THF $(5 \mathrm{~mL})$ were successively added $\mathrm{BuLi}(1.6 \mathrm{M}$ hexanes solution, $6.0 \mathrm{mmol})$ and, $5 \mathrm{~min}$ later, $\mathrm{CdCl}_{2} \cdot \mathrm{TMEDA}^{36}(0.60$ $\mathrm{g}, 2.0 \mathrm{mmol}$ ). The mixture was stirred for $10 \mathrm{~min}$ at $0{ }^{\circ} \mathrm{C}$ before introduction of the required substrate (4.0 mmol). After $2 \mathrm{~h}$ at room temperature, a solution of $\mathrm{I}_{2}(1.5 \mathrm{~g}, 6.0 \mathrm{mmol})$ in THF $(5 \mathrm{~mL})$ was added. The mixture was stirred overnight before addition of an aq saturated solution of $\mathrm{Na}_{2} \mathrm{~S}_{2} \mathrm{O}_{3}(10 \mathrm{~mL})$ and extraction with EtOAc $(3 \times 20 \mathrm{~mL})$. After drying over anhydrous $\mathrm{Na}_{2} \mathrm{SO}_{4}$, the solvent was evaporated under reduced pressure, and the iodide was isolated by purification by flash chromatography on silica gel.

4.8.1. (R)-2-(4-Methoxybenzyloxy)-1-propyl 2-iodoferrocenecarboxylate (diastereoisomeric mixture) (7a) was prepared from 6a (1.6 g) and was isolated (eluent: 94:6 heptane-EtOAc) as a red oil (yield: 76\%): ${ }^{1} \mathrm{H}$ NMR (300 MHz, $\left.\mathrm{CDCl}_{3}\right) \delta 1.32(2 \mathrm{~d}, 3 \mathrm{H}, J=6.4 \mathrm{~Hz}), 3.79$ and $3.80(2 \mathrm{~s}, 3 \mathrm{H}), 3.83-$ $3.94(\mathrm{~m}, 1 \mathrm{H}), 4.21-4.22(2 \mathrm{~s}, 5 \mathrm{H}), 4.17-4.46(\mathrm{~m}, 3 \mathrm{H}), 4.56-4.65(\mathrm{~m}, 2 \mathrm{H}), 4.69-4.71(\mathrm{~m}, 1 \mathrm{H}), 4.85-4.88$ $(\mathrm{m}, 1 \mathrm{H}), 6.90-6.95(\mathrm{~m}, 2 \mathrm{H}), 7.29-7.34(\mathrm{~m}, 2 \mathrm{H}) ;{ }^{13} \mathrm{C} \mathrm{NMR}\left(75 \mathrm{MHz}, \mathrm{CDCl}_{3}\right) \delta 17.5$ (2 peaks), 39.8, 55.4, 67.0, 67.3, 70.4 (2 peaks), 70.8, 70.9, 72.4, 72.6, 72.7, $72.9(5 \mathrm{C}), 76.0,79.9,113.9(2 \mathrm{C}), 129.4(2$ peaks, 2C), 130.7, 159.3, 170.2, 170.3. Anal. Calcd for $\mathrm{C}_{22} \mathrm{H}_{23} \mathrm{FeIO}_{4}$ (534.17): C, 49.47; H, 4.34. Found: C, 49.20; H, 4.21. Treatment with DIBAL-H according to 4.7. (b) afforded 2iodoferrocenemethanol (9) in 94\% yield and 7\% ee $\left(S_{\mathrm{P}}\right)$.

\subsection{2. (R)-2-(tert-Butyldiphenylsilyloxy)-1-propyl 2-iodoferrocenecarboxylate (diastereoisomeric}

mixture) (7b) was prepared from 6b (2.1 g) and was isolated (eluent: 94:6 heptane-Et $\left.{ }_{2} \mathrm{O}\right)$ as a red powder (yield: 54\%): $\mathrm{mp} 126{ }^{\circ} \mathrm{C} ;{ }^{1} \mathrm{H}$ NMR (300 MHz, $\left.\mathrm{CDCl}_{3}\right) \delta 1.08$ and $1.09(2 \mathrm{~s}, 9 \mathrm{H}), 1.21$ and 1.25 $(2 \mathrm{~d}, 3 \mathrm{H}, J=5.9 \mathrm{~Hz}), 4.10-4.22(\mathrm{~m}, 8 \mathrm{H}), 4.41(\mathrm{q}, 1 \mathrm{H}, J=2.7 \mathrm{~Hz}), 4.67-4.69(\mathrm{~m}, 1 \mathrm{H}), 4.77-4.78(\mathrm{~m}$, 1H), 7.33-7.44 (m, 6H), 7.68-7.73 (m, 4H); $\left.{ }^{13} \mathrm{C} \mathrm{NMR} \mathrm{(75} \mathrm{MHz,} \mathrm{CDCl}_{3}\right) \delta 19.4,20.8,27.1$ (3C), 39.8, 67.7, 67.8, 69.4 (2 peaks), 70.3, 72.3 (2 peaks), 72.9 (2 peaks, 5C), 79.9, 127.8 (2 peaks, 4C), 129.8 
(2C), 134.0 (2 peaks), 134.3 (2 peaks), 136.0 (2 peaks, 4C), 170.2. Anal. Calcd for $\mathrm{C}_{30} \mathrm{H}_{33} \mathrm{FeIO}_{3} \mathrm{Si}$ (652.42): C, 55.23; H, 5.10. Found: C, 55.08; H, 5.34. Treatment with DIBAL-H according to 4.7. (b) afforded 2-iodoferrocenemethanol (9) in 98\% yield and 1\% ee $\left(S_{\mathrm{P}}\right)$.

\subsubsection{5-O-(2-Iodoferrocenecarbonyl)-1,2-O-isopropylidene-3-O-methyl- $\alpha$-D-xylofuranose}

(diastereoisomeric mixture) (7d) was prepared from 6d (1.7 g) and was isolated (eluent: 88:12 heptane-EtOAc) as a red oil (yield: $92 \%$ ). The analyses were as described previously. ${ }^{15}$ Treatment with DIBAL-H according to 4.7. (b) afforded 2-iodoferrocenemethanol (9) in 93\% yield and 4\% ee $\left(S_{\mathrm{P}}\right)$. 5$O$-(2,5-Diiodoferrocenecarbonyl)-1,2- $O$-isopropylidene-3- $O$-methyl- $\alpha$-D-xylofuranose (8d) was isolated similarly in 3\% yield as a red liquid, and was identified by NMR: ${ }^{1} \mathrm{H}$ NMR $\left(300 \mathrm{MHz}, \mathrm{CDCl}_{3}\right)$ $\delta 1.34(\mathrm{~s}, 3 \mathrm{H}), 1.52(\mathrm{~s}, 3 \mathrm{H}), 3.46(\mathrm{~s}, 3 \mathrm{H}), 3.95(\mathrm{~d}, 1 \mathrm{H}, J=2.7 \mathrm{~Hz}), 4.26(\mathrm{~s}, 5 \mathrm{H}), 4.52-4.65(\mathrm{~m}, 4 \mathrm{H}), 4.77$ $(\mathrm{s}, 2 \mathrm{H}), 5.97(\mathrm{~d}, 1 \mathrm{H}, J=3.8 \mathrm{~Hz}) ;[\alpha]_{\mathrm{D}}=-19\left(\mathrm{CH}_{2} \mathrm{Cl}_{2}, c=0.11,20{ }^{\circ} \mathrm{C}\right)$.

\subsubsection{6-O-(2-Iodoferrocenecarbonyl)-1,2:3,4-di- $O$-isopropylidene- $\alpha$-D-galactopyranose} (diastereoisomeric mixture) (7e) was prepared from 6e $(1.9 \mathrm{~g})$ and was isolated (eluent: 75:25 heptane- $\mathrm{Et}_{2} \mathrm{O}$ ) as an orange powder (yield: $82 \%$ ). The analyses were as described previously. ${ }^{15}$ Treatment with DIBAL-H according to 4.7. (b) afforded 2-iodoferrocenemethanol (9) in 95\% yield and $8 \%$ ee $\left(S_{\mathrm{P}}\right)$. 6-O -(2,5-Diiodoferrocenecarbonyl)-1,2:3,4-di- $\boldsymbol{O}$-isopropylidene- $\boldsymbol{\alpha}$-D-galactopyranose (8e) was isolated similarly in 4\% yield as a red liquid, and was identified by NMR: ${ }^{1} \mathrm{H}$ NMR (300 $\left.\mathrm{MHz}, \mathrm{CDCl}_{3}\right) \delta 1.34(\mathrm{~s}, 3 \mathrm{H}), 1.36(\mathrm{~s}, 3 \mathrm{H}), 1.49(\mathrm{~s}, 3 \mathrm{H}), 1.60(\mathrm{~s}, 3 \mathrm{H}), 4.29-4.33(\mathrm{~m}, 6 \mathrm{H}), 4.37(\mathrm{dd}, 1 \mathrm{H}, J$ $=5.0,2.5 \mathrm{~Hz}), 4.43-4.49(\mathrm{~m}, 3 \mathrm{H}), 4.67(\mathrm{dd}, 1 \mathrm{H}, J=7.9,2.5 \mathrm{~Hz}), 4.75(\mathrm{~s}, 2 \mathrm{H}), 5.60(\mathrm{~d}, 1 \mathrm{H}, J=5.0 \mathrm{~Hz})$;

${ }^{13} \mathrm{C}$ NMR $\left(75 \mathrm{MHz}, \mathrm{CDCl}_{3}\right) \delta 24.6,25.1,26.2,26.6,39.0,39.4,64.1,66.0,70.5,70.8,71.2,73.1,76.2$ (5C), 80.5, 96.5, 108.9, 109.7, 168.8; $[\alpha]_{\mathrm{D}}=-36\left(\mathrm{CH}_{2} \mathrm{Cl}_{2}, c=0.67,20{ }^{\circ} \mathrm{C}\right)$.

4.8.5. $(1 R, 2 S)-2-[N-($ tert-Butoxycarbonyl)- $N$-methylamino]-1-phenylpropyl 2iodoferrocenecarboxylate (diastereoisomeric mixture) (7f) was prepared from $\mathbf{6 f}(1.9 \mathrm{~g})$ and was isolated (eluent: 8:2 heptane-EtOAc) as a yellow oil (yield: 84\%): ${ }^{1} \mathrm{H}$ NMR $\left(500 \mathrm{MHz}, 340 \mathrm{~K}, \mathrm{C}_{6} \mathrm{D}_{6}\right) \delta$ common signals: $1.27(\mathrm{~d}, 3 \mathrm{H}, J=6.8 \mathrm{~Hz}), 1.34(\mathrm{~s}, 9 \mathrm{H}), 2.57(\mathrm{br} \mathrm{s}, 3 \mathrm{H}), 4.77$ (br s, 1H), 7.08-7.20 (m, 
$3 \mathrm{H})$; major diastereoisomer signals: $3.87(\mathrm{~s}, 5 \mathrm{H}), 3.99(\mathrm{t}, 1 \mathrm{H}, J=2.6 \mathrm{~Hz}), 4.42(\mathrm{dd}, 1 \mathrm{H}, J=2.6,1.6$ $\mathrm{Hz}), 4.73(\mathrm{dd}, 1 \mathrm{H}, J=2.6,1.6 \mathrm{~Hz}), 6.21(\mathrm{~d}, 1 \mathrm{H}, J=8.6 \mathrm{~Hz}), 7.55(\mathrm{~d}, 2 \mathrm{H}, J=6.8 \mathrm{~Hz})$; minor diastereoisomer signals: $3.86(\mathrm{~s}, 5 \mathrm{H}), 3.98(\mathrm{t}, 1 \mathrm{H}, J=2.6 \mathrm{~Hz}), 4.41(\mathrm{dd}, 1 \mathrm{H}, J=2.6,1.6 \mathrm{~Hz}), 4.82(\mathrm{dd}$, $1 \mathrm{H}, J=2.6,1.6 \mathrm{~Hz}), 6.30(\mathrm{~d}, 1 \mathrm{H}, J=8.4 \mathrm{~Hz}), 7.66(\mathrm{~d}, 2 \mathrm{H}, J=7.2 \mathrm{~Hz}) ;{ }^{13} \mathrm{C} \mathrm{NMR}(125 \mathrm{MHz}, 340 \mathrm{~K}$, $\left.\mathrm{C}_{6} \mathrm{D}_{6}\right) \delta$ common signals: 14.9, $28.5(3 \mathrm{C}), 55.2,72.0,72.9(5 \mathrm{C}), 79.2,127.8-128.8(5 \mathrm{C}), 139.5,155.2$; major diastereoisomer signals: $30.2,39.9,70.7,72.3,77.8,80.2,168.5$; minor diastereoisomer signals: 30.3, 39.8, 71.3, 72.5, 78.4, 80.4, 168.8. Anal. Calcd for $\mathrm{C}_{26} \mathrm{H}_{30} \mathrm{FeINO}_{4}$ (603.27): C, 51.76; H, 5.01; N, 2.32. Found: C, 52.09; H, 5.17; N, 2.27. Treatment with DIBAL-H according to 4.7. (b) afforded 2iodoferrocenemethanol (9) in 93\% yield and 30\% ee $\left(S_{\mathrm{P}}\right)$. (1R,2S)-2-[N-(tert-Butoxycarbonyl)- $N$ methylamino]-1-phenylpropyl 2,5-diiodoferrocenecarboxylate (8f) was isolated similarly in 9\% yield as a yellow oil, and was identified by NMR: ${ }^{1} \mathrm{H}$ NMR $\left(500 \mathrm{MHz}, 340 \mathrm{~K}, \mathrm{C}_{6} \mathrm{D}_{6}\right) \delta 1.35(\mathrm{~s}, 9 \mathrm{H})$, $1.38(\mathrm{~d}, 3 \mathrm{H}, J=6.8 \mathrm{~Hz}), 2.57$ (br s, 3H), $3.86(\mathrm{~s}, 5 \mathrm{H}), 4.34(\mathrm{~m}, 2 \mathrm{H}), 4.98(\mathrm{br} \mathrm{s}, 1 \mathrm{H}), 6.28(\mathrm{~d}, 1 \mathrm{H}, J=9.2$ $\mathrm{Hz}), 7.09(\mathrm{t}, 1 \mathrm{H}, J=7.6 \mathrm{~Hz}), 7.19(\mathrm{t}, 2 \mathrm{H}, J=7.6 \mathrm{~Hz}), 7.70(\mathrm{~d}, 2 \mathrm{H}, J=7.6 \mathrm{~Hz}) ;{ }^{13} \mathrm{C} \mathrm{NMR}(125 \mathrm{MHz}$, $\left.340 \mathrm{~K}, \mathrm{C}_{6} \mathrm{D}_{6}\right) \delta 15.5,28.5(3 \mathrm{C}), 30.2,39.0,39.6,55.0,73.0,75.9(5 \mathrm{C}), 79.0,79.2,81.2,81.2,127.5-$ $128.8(5 \mathrm{C}), 139.1,155.2,167.2 ;[\alpha]_{\mathrm{D}}=+37.5\left(\mathrm{CH}_{2} \mathrm{Cl}_{2}, c=0.93,20{ }^{\circ} \mathrm{C}\right)$.

\subsubsection{5-(tert-Butoxycarbonylamino)-5-deoxy-3-O-(2-iodoferrocenecarbonyl)-1,2-O-} isopropylidene- $\alpha$-D-xylofuranose (diastereoisomeric mixture) (7m) was prepared similarly from $\mathbf{6 m}$ $(2.0 \mathrm{~g})$ but after treatment of the substrate with BuLi (1.6 M hexane solution, $4.0 \mathrm{mmol})$, and was isolated (eluent: 96:4 to 90:10 heptane-EtOAc) as an orange solid (yield: 48\%). A 52\% de was

estimated by NMR. The analyses were as described previously. ${ }^{15}$ Treatment with DIBAL-H according to 4.7. (b) afforded 2-iodoferrocenemethanol (9) in 94\% yield and $40 \%$ ee $\left(S_{\mathrm{P}}\right)$.

4.9. General procedure for the deprotonation using the lithium-zinc base prepared from $\mathrm{ZnCl}_{2} \cdot \mathrm{TMEDA}\left(1\right.$ equiv) and $\mathrm{Li}(\mathrm{TMP})\left(3\right.$ equiv) in THF followed by trapping using $\mathrm{I}_{2}$. To a stirred cooled $\left(0^{\circ} \mathrm{C}\right)$ solution of 2,2,6,6-tetramethylpiperidine $(1.1 \mathrm{~mL}, 6.0 \mathrm{mmol})$ in THF $(5 \mathrm{~mL})$ were successively added BuLi (1.6 M hexanes solution, $6.0 \mathrm{mmol})$ and, $5 \mathrm{~min}$ later, $\mathrm{ZnCl}_{2} \cdot \mathrm{TMEDA}^{7 \mathrm{e}}(0.51$ 
$\mathrm{g}, 2.0 \mathrm{mmol}$ ). The mixture was stirred for $10 \mathrm{~min}$ at $0{ }^{\circ} \mathrm{C}$ before introduction of the required substrate ( $2.0 \mathrm{mmol})$. After $2 \mathrm{~h}$ at room temperature, a solution of $\mathrm{I}_{2}(1.5 \mathrm{~g}, 6.0 \mathrm{mmol})$ in THF $(5 \mathrm{~mL})$ was added. The mixture was stirred overnight before addition of an aq saturated solution of $\mathrm{Na}_{2} \mathrm{~S}_{2} \mathrm{O}_{3}(10 \mathrm{~mL})$ and extraction with EtOAc $(3 \times 20 \mathrm{~mL})$. After drying over anhydrous $\mathrm{Na}_{2} \mathrm{SO}_{4}$, the solvent was evaporated under reduced pressure, and the iodide was isolated by purification by flash chromatography on silica gel.

4.9.1. (2S,4R)-1-tert-Butoxycarbonyl-2-(tert-butyldiphenylsilyloxymethyl)-4-pyrrolidyl 2iodoferrocenecarboxylate (diastereoisomeric mixture) $(\mathbf{7 g})$ was prepared from $\mathbf{6 g}(1.3 \mathrm{~g})$ and was isolated (eluent: 95:5 heptane-EtOAc) as an orange gum (yield: 73\%): ${ }^{1} \mathrm{H} \mathrm{NMR}\left(300 \mathrm{MHz}, \mathrm{CDCl}_{3}\right) \delta$ $1.05(\mathrm{~s}, 9 \mathrm{H}), 1.34$ and $1.46(\mathrm{~s}, 9 \mathrm{H}), 2.21-2.59(\mathrm{~m}, 2 \mathrm{H}), 3.57-3.86(\mathrm{~m}, 3 \mathrm{H}), 3.98-4.25(\mathrm{~m}, 2 \mathrm{H}), 4.21$ and $4.22(\mathrm{~s}, 5 \mathrm{H}), 4.44-4.46(\mathrm{~m}, 1 \mathrm{H}), 4.69$ (br s, 1H), 4.82-4.89 (m, 1H), 5.50-5.52 (m, 1H), 7.35-7.43 (m, $6 \mathrm{H})$, 7.63-7.67 (m, 4H); HRMS: calcd for $\mathrm{C}_{37} \mathrm{H}_{44}{ }^{56} \mathrm{FeINNaO}_{5} \mathrm{Si}\left[(\mathrm{M}+\mathrm{Na})^{+\bullet}\right]$ 816.1275, found 816.1276. Treatment with DIBAL-H according to 4.7. (b) afforded 2-iodoferrocenemethanol (9) in 94\% yield and $33 \%$ ee $\left(S_{\mathrm{P}}\right)$.

\subsubsection{3-O-(2-Iodoferrocenecarbonyl)-5-O-(tert-butyldiphenylsilyl)-1,2-O-isopropylidene- $\alpha$-D-} xylofuranose (diastereoisomeric mixture) (7h) was prepared from $6 \mathbf{h}(1.3 \mathrm{~g})$ and was isolated (eluent: 93:7 heptane-EtOAc) as an orange solid (yield: 86\%). A 20\% de was estimated by NMR. The analyses were as described previously. ${ }^{15}$ Treatment with DIBAL-H according to 4.7. (b) afforded 2iodoferrocenemethanol (9) in $61 \%$ yield and $22 \%$ ee $\left(R_{\mathrm{P}}\right)$.

\subsection{1-O-(2-Iodoferrocenecarbonyl)-2,3:5,6-di- $O$-cyclohexylidene- $\alpha$-D-mannofuranose}

(diastereoisomeric mixture) (7i). To a stirred cooled $\left(0^{\circ} \mathrm{C}\right)$ solution of 2,2,6,6-tetramethylpiperidine $(1.1 \mathrm{~mL}, 6.0 \mathrm{mmol})$ in THF $(5 \mathrm{~mL})$ were successively added BuLi (1.6 M hexanes solution, $6.0 \mathrm{mmol})$ and, $5 \mathrm{~min}$ later, $\mathrm{CdCl}_{2} \cdot \mathrm{TMEDA}^{36}(0.60 \mathrm{~g}, 2.0 \mathrm{mmol})$. The mixture was stirred for $10 \mathrm{~min}$ at $0{ }^{\circ} \mathrm{C}$ before introduction of $6 \mathbf{i}(1.1 \mathrm{~g}, 1.3 \mathrm{mmol})$. After $2 \mathrm{~h}$ at room temperature, a solution of $\mathrm{I}_{2}(1.5 \mathrm{~g}, 6.0$ $\mathrm{mmol})$ in THF (5 mL) was added. The mixture was stirred overnight before addition of an aq saturated 
solution of $\mathrm{Na}_{2} \mathrm{~S}_{2} \mathrm{O}_{3}(10 \mathrm{~mL})$ and extraction with EtOAc $(3 \times 20 \mathrm{~mL})$. After drying over anhydrous $\mathrm{Na}_{2} \mathrm{SO}_{4}$, the solvent was evaporated under reduced pressure, and the iodide $7 \mathbf{i}$ was purified by purification by flash chromatography on silica gel. Compound 7i could not be separated from the starting material (estimated yield: 67\%). A 48\% de was estimated by NMR. The analyses were as described previously. ${ }^{15}$ The treatment of a fraction containing only the main diastereoisomer with DIBAL-H according to 4.7. (b) afforded $\left(S_{\mathrm{P}}\right)$-2-iodoferrocenemethanol $\left(\left(\boldsymbol{S}_{\mathbf{P}}\right)-\mathbf{9}\right)$.

4.11. 3-O-(2-Iodoferrocenecarbonyl)-1,2:5,6-di- $O$-isopropylidene- $\alpha$-D-glucofuranose (diastereoisomeric mixture) (7j). To a stirred cooled $\left(0^{\circ} \mathrm{C}\right)$ solution of 2,2,6,6-tetramethylpiperidine $(1.1 \mathrm{~mL}, 6.0 \mathrm{mmol})$ in THF $(5 \mathrm{~mL})$ was added BuLi (1.6 M hexanes solution, $6.0 \mathrm{mmol})$. After $5 \mathrm{~min}$, this solution was transferred at $-10{ }^{\circ} \mathrm{C}$ to $\mathrm{CdCl}_{2}(0.37 \mathrm{~g}, 2.0 \mathrm{mmol})$ dried by heating under vacuum. The mixture was stirred for $10 \mathrm{~min}$ at $0{ }^{\circ} \mathrm{C}$ before introduction of $\mathbf{6 j}(0.94 \mathrm{~g}, 2.0 \mathrm{mmol})$. After $2 \mathrm{~h}$ at room temperature, a solution of $\mathrm{I}_{2}(1.5 \mathrm{~g}, 6.0 \mathrm{mmol})$ in $\mathrm{THF}(5 \mathrm{~mL})$ was added. The mixture was stirred overnight before addition of an aq saturated solution of $\mathrm{Na}_{2} \mathrm{~S}_{2} \mathrm{O}_{3}(10 \mathrm{~mL})$ and extraction with EtOAc (3 x $20 \mathrm{~mL}$ ). After drying over anhydrous $\mathrm{Na}_{2} \mathrm{SO}_{4}$, the solvent was evaporated under reduced pressure, and the iodide $\mathbf{7} \mathbf{j}$ was isolated by purification by flash chromatography on silica gel. It was isolated (eluent: 93:7 heptane-EtOAc) in 87\% yield. A $82 \%$ de was determined by NMR. The analyses of both diastereoisomers were as described previously. ${ }^{15}$ The treatment of a fraction containing only the $\left(R_{\mathrm{P}}\right)$ diastereoisomer with DIBAL-H according to 4.7. (b) afforded $\left(R_{\mathrm{P}}\right)$-2-iodoferrocenemethanol $\left(\left(\boldsymbol{R}_{\mathbf{P}}\right)-\mathbf{9}\right)$ in $93 \%$ yield. The treatment of a fraction containing only the $\left(S_{\mathrm{P}}\right)$-diastereoisomer with DIBAL-H according to 4.7. (b) afforded $\left(S_{\mathrm{P}}\right)$-2-iodoferrocenemethanol $\left(\left(\boldsymbol{S}_{\mathbf{P}}\right)-\mathbf{9}\right)$ in $95 \%$ yield.

\subsection{2. $\left(R_{\mathrm{P}}\right)-6$-(tert-Butoxycarbonylamino)-6-deoxy-5-O-(2-iodoferrocenecarbonyl)-1,2-O-}

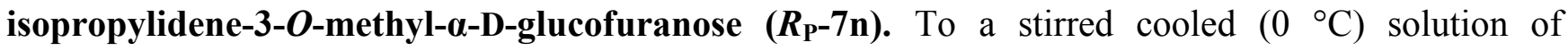
2,2,6,6-tetramethylpiperidine $(0.68 \mathrm{~mL}, 4.0 \mathrm{mmol})$ in THF $(5 \mathrm{~mL})$ was added BuLi $(1.6 \mathrm{M}$ hexanes solution, $4.0 \mathrm{mmol})$. After $5 \mathrm{~min}$, the solution was cooled at $-10{ }^{\circ} \mathrm{C}$ and added to $\mathrm{ZnCl}_{2}(0.27 \mathrm{~g}, 2.0$ mmol). The mixture was stirred for $10 \mathrm{~min}$ at $0{ }^{\circ} \mathrm{C}$ and transferred to $6 \mathbf{n}(1.1 \mathrm{~g}, 2.0 \mathrm{mmol})$ in $\mathrm{THF}(5$ 
$\mathrm{mL})$. After $10 \mathrm{~min}$ at room temperature, a cooled $\left(-30^{\circ} \mathrm{C}\right)$ solution prepared in $\mathrm{THF}(5 \mathrm{~mL})$ from 2,2,6,6-tetramethylpiperidine $(0.68 \mathrm{~mL}, 4.0 \mathrm{mmol})$ and BuLi (1.6 M hexanes solution, $4.0 \mathrm{mmol})$ was added, and the resulting mixture was stirred for $2 \mathrm{~h}$ at room temperature before a solution of $\mathrm{I}_{2}(2.0 \mathrm{~g}$, $8.0 \mathrm{mmol})$ in THF $(5 \mathrm{~mL})$ was added. The mixture was stirred overnight before addition of an aq saturated solution of $\mathrm{Na}_{2} \mathrm{~S}_{2} \mathrm{O}_{3}(10 \mathrm{~mL})$ and extraction with EtOAc $(3 \times 20 \mathrm{~mL})$. After drying over anhydrous $\mathrm{Na}_{2} \mathrm{SO}_{4}$, the solvent was evaporated under reduced pressure, and the iodide $\boldsymbol{R}_{\mathbf{P}}-\mathbf{7 n}$ was isolated by purification by flash chromatography on silica gel. It was isolated (eluent: 7:3 heptaneEtOAc) as an orange gum (yield: $57 \%$ ). The analyses were as described previously. ${ }^{15}$

4.13. Meso-2,2"-Bis(methoxycarbonyl)-1,1"-biferrocene (meso-10o) was synthesized by adapting a described procedure. ${ }^{27}$ Treating under argon a solution of racemic methyl 2-iodoferrocenecarboxylate (rac-7o, $0.72 \mathrm{~g}, 2.0 \mathrm{mmol})$ in toluene $(15 \mathrm{~mL})$ by $\mathrm{NaH}(60 \%$ in a mineral oil, $0.64 \mathrm{~g}, 16 \mathrm{mmol})$, $\mathrm{NiCl}_{2}\left(\mathrm{PPh}_{3}\right)_{2}(1.3 \mathrm{~g}, 2.0 \mathrm{mmol}), \mathrm{PPh}_{3}(1.0 \mathrm{~g}, 4 \mathrm{mmol})$, and $\mathrm{Zn}$ (powder, $\left.0.52 \mathrm{~g}, 8.0 \mathrm{mmol}\right)$ resulted in a mixture that was heated at $75^{\circ} \mathrm{C}$ for $12 \mathrm{~h}$. Quenching at room temperature with $5 \% \mathrm{HCl}$, extraction with $\mathrm{Et}_{2} \mathrm{O}(2 \times 10 \mathrm{~mL})$ and $\mathrm{CH}_{2} \mathrm{Cl}_{2}(10 \mathrm{~mL})$, washing of the combined organic layers with brine $(2 \times 10$ $\mathrm{mL}$ ), drying over $\mathrm{Na}_{2} \mathrm{SO}_{4}$, and purification by flash chromatography on silica gel (eluent: 9:1 heptaneEtOAc) afforded meso-10o as an orange solid (yield: $53 \%$ ): $\mathrm{mp} 159{ }^{\circ} \mathrm{C} ;{ }^{1} \mathrm{H} \mathrm{NMR}\left(300 \mathrm{MHz}, \mathrm{CDCl}_{3}\right) \delta$ $4.81(\mathrm{~s}, 6 \mathrm{H}), 4.07(\mathrm{~s}, 10 \mathrm{H}), 4.43(\mathrm{t}, 2 \mathrm{H}, J=2.6 \mathrm{~Hz}), 4.82(\mathrm{dd}, 2 \mathrm{H}, J=1.6,2.6 \mathrm{~Hz}), 4.99(\mathrm{dd}, 2 \mathrm{H}, J=$ 1.6, 2.6 Hz); ${ }^{13} \mathrm{C}$ NMR (75 MHz, $\left.\mathrm{CDCl}_{3}\right) \delta 51.6(2 \mathrm{C}), 69.5$ (2C), $69.6(2 \mathrm{C}), 70.4(2 \mathrm{C}), 71.5$ (10C), 76.9 (2C), 85.6 (2C), 172.0 (2C); HRMS: calcd for $\mathrm{C}_{24} \mathrm{H}_{22}{ }^{56} \mathrm{Fe}_{2} \mathrm{NaO}_{4}\left[(\mathrm{M}+\mathrm{Na})^{+\bullet}\right] \quad 509.0109$ and $\mathrm{C}_{24} \mathrm{H}_{22}{ }^{56} \mathrm{Fe}_{2} \mathrm{O}_{4}\left(\mathrm{M}^{+\bullet}\right)$ 486.0211, found 509.0110 and 486.0231. The structure of meso-10o was identified unequivocally by X-ray structure analysis (CCDC 970488) from crystals obtained by slowly evaporating a 7:3 hexane- $\mathrm{CH}_{2} \mathrm{Cl}_{2}$ solution. 2,2"-Bis(methoxycarbonyl)-1,1"-biferrocene (racemic mixture) (rac-10'o) was obtained similarly (eluent: 7:3 heptane-EtOAc) as an orange solid (yield: 15\%): mp $185{ }^{\circ} \mathrm{C} ;{ }^{1} \mathrm{H}$ NMR (300 MHz, $\left.\mathrm{CDCl}_{3}\right) \delta 3.62(\mathrm{~s}, 6 \mathrm{H}), 4.20(\mathrm{~s}, 10 \mathrm{H}), 4.45(\mathrm{t}, 2 \mathrm{H}, J=2.6 \mathrm{~Hz})$, 4.83-4.81 (m, 3H); ${ }^{13} \mathrm{C}$ NMR (75 MHz, $\left.\mathrm{CDCl}_{3}\right) \delta 51.3$ (2C), 69.1 (2C), 70.0 (2C), 71.0 (10C), 71.7 
(2C), 76.4 (2C), 85.1 (2C), 172.0 (2C); HRMS: calcd for $\mathrm{C}_{24} \mathrm{H}_{22}{ }^{56} \mathrm{Fe}_{2} \mathrm{NaO}_{4}\left[(\mathrm{M}+\mathrm{Na})^{+\bullet}\right] 509.0109$ and $\mathrm{C}_{24} \mathrm{H}_{22}{ }^{56} \mathrm{Fe}_{2} \mathrm{O}_{4}\left(\mathrm{M}^{+\bullet}\right)$ 486.0211, found 509.0110 and 486.0213. The structure of rac-10'o was identified unequivocally by X-ray structure analysis (CCDC 970489) from crystals obtained by slowly evaporating a 7:3 hexane- $\mathrm{CH}_{2} \mathrm{Cl}_{2}$ solution.

4.14. General procedure for the Suzuki coupling. A solution of the required iodoferrocene 7 (0.5 $\mathrm{mmol})$, the required boronic acid $(2.0 \mathrm{mmol})$, and $\mathrm{CsF}(0.15 \mathrm{~g}, 1.0 \mathrm{mmol})$ in the toluene $(5 \mathrm{~mL})$ was degassed with $\mathrm{Ar}$ for $30 \mathrm{~min}$ before addition of $\mathrm{Pd}(\mathrm{dba})_{2}(14 \mathrm{mg}, 25 \mu \mathrm{mol})$, and $\mathrm{PPh}_{3}(26 \mathrm{mg}, 0.10$ mmol). The resulting mixture was heated for $12 \mathrm{~h}$ under reflux before cooling and dilution with $\mathrm{Et}_{2} \mathrm{O}$ (30 mL), washing with $\mathrm{H}_{2} \mathrm{O}$, and extraction with $\mathrm{CH}_{2} \mathrm{Cl}_{2}(3 \times 20 \mathrm{~mL})$. After drying over anhydrous $\mathrm{Na}_{2} \mathrm{SO}_{4}$, the solvent was evaporated under reduced pressure, and the iodide was isolated by purification by flash chromatography on silica gel.

4.14.1. Methyl 2-(4-methoxyphenyl)ferrocenecarboxylate (racemic mixture) (rac-110) was prepared from racemic methyl 2-iodoferrocenecarboxylate (rac-7o, 0.18 g) and 4methoxyphenylboronic acid (0.30 g). It was isolated (eluent: 93:7 heptane-EtOAc) as an orange gum (yield: 97\%): ${ }^{1} \mathrm{H}$ NMR (300 MHz, $\left.\mathrm{CDCl}_{3}\right) \delta 3.76$ (s, 3H), 3.83 (s, 3H), $4.20(\mathrm{~s}, 5 \mathrm{H}), 4.45(\mathrm{t}, 1 \mathrm{H}, J=2.6$ Hz), $4.56(\mathrm{dd}, 1 \mathrm{H}, J=1.6,2.5 \mathrm{~Hz}), 4.88(\mathrm{dd}, 1 \mathrm{H}, J=1.6,2.6 \mathrm{~Hz}), 6.87(\mathrm{~d}, 2 \mathrm{H}, J=8.8 \mathrm{~Hz}), 7.55(\mathrm{~d}, 2 \mathrm{H}$, $J=8.8 \mathrm{~Hz}) ;{ }^{13} \mathrm{C} \mathrm{NMR}\left(75 \mathrm{MHz}, \mathrm{CDCl}_{3}\right) \delta 51.2,55.0,68.3,69.5,70.9(5 \mathrm{C}), 71.1,73.7,90.8,112.6$ (2C), 128.6, 131.1 (2C), 158.4, 171.7; HRMS: calcd for $\mathrm{C}_{19} \mathrm{H}_{18}{ }^{56} \mathrm{FeNaO}_{3}\left[(\mathrm{M}+\mathrm{Na})^{+\bullet}\right] 373.0503$, found 373.0500 .

\subsection{2. $\quad\left(R_{\mathrm{P}}\right)-3-O$-(2-(4-Methoxyphenyl)ferrocenecarbonyl)-1,2:5,6-di- $O$-isopropylidene- $\alpha$-D-} glucofuranose $\left(\boldsymbol{R}_{\mathbf{P}^{-}} \mathbf{1 1} \mathbf{j}\right)$ was prepared from $\boldsymbol{S}_{\mathbf{P}^{-}} \mathbf{7} \mathbf{j}(0.30 \mathrm{~g})$ and 4-methoxyphenylboronic acid $(0.30 \mathrm{~g})$. It was isolated (eluent: 93:7 heptane-EtOAc) as an orange gum (yield: 98\%): ${ }^{1} \mathrm{H} \mathrm{NMR}\left(300 \mathrm{MHz}, \mathrm{CDCl}_{3}\right)$ $\delta 1.28(\mathrm{~s}, 3 \mathrm{H}), 1.33(\mathrm{~s}, 3 \mathrm{H}), 1.43(\mathrm{~s}, 3 \mathrm{H}), 1.53(\mathrm{~s}, 3 \mathrm{H}), 3.83(\mathrm{~s}, 3 \mathrm{H}), 4.07-4.28(\mathrm{~m}, 4 \mathrm{H}), 4.26(\mathrm{~s}, 5 \mathrm{H})$, $4.48(\mathrm{t}, 1 \mathrm{H}, J=2.6 \mathrm{~Hz}), 4.54(\mathrm{~d}, 1 \mathrm{H}, J=3.6 \mathrm{~Hz}), 4.61(\mathrm{dd}, 1 \mathrm{H}, J=1.6,2.6 \mathrm{~Hz}), 4.88(\mathrm{dd}, 1 \mathrm{H}, J=1.6$, $2.6 \mathrm{~Hz}), 5.38(\mathrm{~d}, 1 \mathrm{H}, J=2.8 \mathrm{~Hz}), 5.86(\mathrm{~d}, 1 \mathrm{H}, J=3.6 \mathrm{~Hz}), 6.87(\mathrm{~d}, 2 \mathrm{H}, J=8.8 \mathrm{~Hz}), 7.58(\mathrm{~d}, 2 \mathrm{H}, J=8.8$ 
$\mathrm{Hz}) ;{ }^{13} \mathrm{C} \mathrm{NMR}\left(75 \mathrm{MHz}, \mathrm{CDCl}_{3}\right) \delta 25.3,26.1,26.7,27.0,55.2,67.1,67.5,70.0,71.2(5 \mathrm{C}), 72.3,74.2$, $75.5,80.1,83.3,91.4,105.1,109.5,112.2,112.8(2 \mathrm{C}), 128.3,131.4(2 \mathrm{C}), 158.7,170.1 ;[\alpha]_{\mathrm{D}}=-13.7$ $\left(\mathrm{CHCl}_{3}, c=2.4,20{ }^{\circ} \mathrm{C}\right)$; HRMS: calcd for $\mathrm{C}_{30} \mathrm{H}_{34}{ }^{56} \mathrm{FeNaO}_{8}\left[(\mathrm{M}+\mathrm{Na})^{+\bullet}\right]$ 601.1495, found 601.1493.

4.14.3. $\left(S_{\mathrm{P}}\right)-6-($ tert-Butoxycarbonylamino)-6-deoxy-5-O-[2-(4methoxyphenyl)ferrocenecarbonyl]-1,2-O-isopropylidene-3- $O$-methyl- $\alpha$-D-glucofuranose $\left(S_{\mathrm{P}}-11 \mathrm{n}\right)$ was prepared from $\boldsymbol{R}_{\mathbf{P}}-7 \mathbf{n}(0.34 \mathrm{~g})$ and 4-methoxyphenylboronic acid (0.30 g). It was isolated (eluent: 8:2 heptane-EtOAc) as an orange gum (yield: 96\%): ${ }^{1} \mathrm{H}$ NMR $\left(300 \mathrm{MHz}, \mathrm{CDCl}_{3}\right) \delta 1.31(\mathrm{~s}, 3 \mathrm{H}), 1.42$ (s, 9H), $1.49(\mathrm{~s}, 3 \mathrm{H}), 3.32(\mathrm{~s}, 3 \mathrm{H}), 3.44(\mathrm{dt}, 1 \mathrm{H}, J=6.2,12.5 \mathrm{~Hz}), 3.65(\mathrm{~d}, 1 \mathrm{H}, J=3.6 \mathrm{~Hz}), 3.74$ (ddd, $1 \mathrm{H}, J=4.0,5.8,14.2 \mathrm{~Hz}), 3.82(\mathrm{~s}, 3 \mathrm{H}), 4.20-4.26(\mathrm{~m}, 1 \mathrm{H}), 4.24(\mathrm{~s}, 5 \mathrm{H}), 4.46(\mathrm{t}, 1 \mathrm{H}, J=2.5 \mathrm{~Hz}), 4.53$ $(\mathrm{d}, 1 \mathrm{H}, J=3.7 \mathrm{~Hz}), 4.56(\mathrm{dd}, 1 \mathrm{H}, J=1.6,2.5 \mathrm{~Hz}), 4.87-4.96(\mathrm{~m}, 2 \mathrm{H}), 5.19-5.25(\mathrm{~m}, 1 \mathrm{H}), 5.88(\mathrm{~d}, 1 \mathrm{H}, J$ $=3.7 \mathrm{~Hz}), 6.86(\mathrm{~d}, 2 \mathrm{H}, J=8.8 \mathrm{~Hz}), 7.54(\mathrm{~d}, 2 \mathrm{H}, J=8.8 \mathrm{~Hz}) ;{ }^{13} \mathrm{C} \mathrm{NMR}\left(75 \mathrm{MHz}, \mathrm{CDCl}_{3}\right) \delta 26.2,26.7$, 28.4 (3C), 42.0, 55.2, 57.8, 67.9, 69.2, 69.8, 71.0, 71.2 (5C), 74.1, 79.1, 79.9, 81.0, 83.7, 91.4, 105.0, 111.7, $112.8(2 \mathrm{C}), 128.6,131.3,155.7,158.6,170.6 ;[\alpha]_{\mathrm{D}}=+3.93\left(\mathrm{CHCl}_{3}, c=1.6,20{ }^{\circ} \mathrm{C}\right)$; HRMS: calcd for $\mathrm{C}_{33} \mathrm{H}_{41}{ }^{56} \mathrm{FeNNaO}_{9}\left[(\mathrm{M}+\mathrm{Na})^{+\bullet}\right]$ 601.1495, found 601.1493.

Acknowledgments. We gratefully acknowledge Rennes Métropole, Région Bretagne, University of Rennes 1 and CNRS for financial support given to G.D., A.S. and D.V.R. We thank Thermo Fischer for generous gift of 2,2,6,6-tetramethylpiperidine. F.M. also thanks the Institut Universitaire de France and Rennes Métropole. This research has been partly performed as part of the Indo-French "Joint Laboratory for Sustainable Chemistry at Interfaces”.

Supplementary data. CIF files and X-ray crystallographic data for 2c, 6c-e, 6i-l, meso-10o and rac10'0. NMR spectra for 2c, 5g, 6a-c, 6f,g, 7a,b,f,g, 8a,d-f,n, meso-10o, rac-10'o, $R_{\mathrm{P}}-11 \mathrm{j}, S_{\mathrm{P}}-11 \mathrm{n}$ and rac-110. These data can be found in the online version, at http://dx.doi.org/10.1016/j.tet.xxxxxxxxxx.

\section{References and Notes}


1. (a) Gschwend, H. W.; Rodriguez, H. R. Org. React. 1979, 26, 1-360; (b) Beak, P.; Snieckus, V. Acc. Chem. Res. 1982, 15, 306-312; (c) Snieckus, V. Chem. Rev. 1990, 90, 879-933; (d) Gant, T. G.; Meyers, A. I. Tetrahedron 1994, 50, 2297-2360; (e) Schlosser, M. Organometallics in Synthesis 2002, 2nd ed. (Ed.: Schlosser, M.), Wiley: New York, Chapter I.

2. $\quad$ See for example: Eaton, P. E.; Lee, C. H.; Xiong, Y. J. Am. Chem. Soc. 1989, 111, 8016-8018.

3. (a) Harrison-Marchand, A.; Mongin, F. Chem. Rev. 2013, 113, 7470-7562; (b) Mongin, F.; Harrison-Marchand, A. Chem. Rev. 2013, 113, 7563-7727.

4. (a) Schlosser, M. Pure Appl. Chem. 1988, 60, 1627-1634; (b) Lochmann, L. Eur. J. Inorg. Chem. 2000, 1115-1126.

5. $\quad$ Gros, P. C.; Fort, Y. Eur. J. Org. Chem. 2009, 4199-4209.

6. For reviews, see: (a) Mulvey, R. E. Organometallics 2006, 25, 1060-1075; (b) Mulvey, R. E.; Mongin, F.; Uchiyama, M.; Kondo, Y. Angew. Chem. Int. Ed. 2007, 46, 3802-3824; (c) Mulvey, R. E. Acc. Chem. Res. 2009, 42, 743-755; (d) Haag, B.; Mosrin, M.; Ila, H.; Malakhov, V.; Knochel, P. Angew. Chem. Int. Ed. 2011, 50, 9794-9824; (e) Mongin, F.; Uchiyama, M. Curr. Org. Chem. 2011, 15, 2340-2361.

7. (a) Seggio, A.; Lannou, M.-I.; Chevallier, F.; Nobuto, D.; Uchiyama, M.; Golhen, S.; Roisnel, T.; Mongin, F. Chem. Eur. J. 2007, 13, 9982-9989; (b) Seggio, A.; Chevallier, F.; Vaultier, M.; Mongin, F. J. Org. Chem. 2007, 72, 6602-6605; (c) L'Helgoual'ch, J. M.; Seggio, A.; Chevallier, F.; Yonehara, M.; Jeanneau, E.; Uchiyama, M.; Mongin, F. J. Org. Chem. 2008, 73, 177-183; (d) Dayaker, G.; Sreeshailam, A.; Chevallier, F.; Roisnel, T.; Radha Krishna, P.; Mongin, F. Chem. Commun. 2010, 46, 2862-2864; (e) Snégaroff, K.; Komagawa, S.; Chevallier, F.; Gros, P. C.; Golhen, S.; Roisnel, T.; Uchiyama, M.; Mongin, F. Chem. Eur. J. 2010, 16, 8191-8201; (f) Chevallier, F.; Halauko, Y. S.; Pecceu, C.; Nassar, I. F.; Dam, T. U.; Roisnel, T.; Matulis, V. E.; Ivashkevich, O. A.; Mongin, F. Org. Biomol. Chem. 2011, 9, 46714684; (g) Chevallier, F.; Blin, T.; Nagaradja, E.; Lassagne, F.; Roisnel, T.; Halauko, Y. S.; Matulis, V. E.; Ivashkevich, O. A.; Mongin, F. Org. Biomol. Chem. 2012, 10, 4878-4885; (h) Kadiyala, R. R.; Tilly, D.; Nagaradja, E.; Roisnel, T.; Matulis, V. E.; Ivashkevich, O. A.; Halauko, Y. S.; Chevallier, F.; Gros, P. C.; Mongin, F. Chem. Eur. J. 2013, 19, 7944-7960; (i) García-Álvarez, P.; Mulvey, R. E.; Parkinson, J. A. Angew. Chem. Int. Ed. 2011, 50, 96689671.

8. (a) L'Helgoual'ch, J. M.; Bentabed-Ababsa, G.; Chevallier, F.; Yonehara, M.; Uchiyama, M.; Derdour, A.; Mongin, F. Chem. Commun. 2008, 5375-5377; (b) L'Helgoual'ch, J. M.; BentabedAbabsa, G.; Chevallier, F.; Derdour, A.; Mongin, F. Synthesis 2008, 4033-4035; (c) Snégaroff, K.; L'Helgoual'ch, J. M.; Bentabed-Ababsa, G.; Nguyen, T. T.; Chevallier, F.; Yonehara, M.; Uchiyama, M.; Derdour, A.; Mongin, F. Chem. Eur. J. 2009, 15, 10280-10290; (d) BentabedAbabsa, G.; Blanco, F.; Derdour, A.; Mongin, F.; Trécourt, F.; Queguiner, G.; Ballesteros, R.; Abarca, B. J. Org. Chem. 2009, 74, 163-169; (e) Snégaroff, K.; Lassagne, F.; Bentabed-Ababsa, G.; Nassar, E.; Cheikh Sid Ely, S.; Hesse, S.; Perspicace, E.; Derdour, A.; Mongin, F. Org. Biomol. Chem. 2009, 7, 4782-4788; (f) Bentabed-Ababsa, G.; Cheikh Sid Ely, S.; Hesse, S.; Nassar, E.; Chevallier, F.; Nguyen, T. T.; Derdour, A.; Mongin, F. J. Org. Chem. 2010, 75, 839847; (g) Snégaroff, K.; Komagawa, S.; Yonehara, M.; Chevallier, F.; Gros, P. C.; Uchiyama, M.; Mongin, F. J. Org. Chem. 2010, 75, 3117-3120; (h) Armstrong, D. R.; Kennedy, A. R.; Mulvey, R. E.; Parkinson, J. A.; Robertson, S. D. Chem. Sci. 2012, 3, 2700-2707.

9. (a) Togni, A. Angew. Chem., Int. Ed. Engl. 1996, 35, 1475-1477; (b) Gómez-Arrayás, R.; Adrio, J.; Carretero, J. C. Angew. Chem. Int. Ed. 2006, 45, 7674-7715; (c) Butler, I. R. Eur. J. Inorg. Chem. 2012, 2012, 4387-4406.

10. Long, N. J. Angew. Chem., Int. Ed. Engl. 1995, 34, 21-38.

11. van Staveren, D. R.; Metzler-Nolte, N. Chem. Rev. 2004, 104, 5931-5985.

12. Stoll, A. H.; Mayer, P.; Knochel, P. Organometallics 2007, 26, 6694-6697. 
13. (a) Clayden, J. Topics in Organometallic Chemistry 2003, 5, 251-286; (b) Atkinson, R. C. J.; Gibson, V. C.; Long, N. J. Chem. Soc. Rev. 2004, 33, 313-328; (c) Ferber, B.; Kagan, H. B. Adv. Synth. Catal. 2007, 349, 493-507; (d) Deng, W.-P.; Snieckus, V.; Metallinos, C. Chiral Ferrocenes in Asymmetric Catalysis: Synthesis and Applications; Wiley-VCH: Weinheim, 2010; (e) Schaarschmidt, D.; Lang, H. Organometallics 2013, 32, 5668-5704.

14. Sreeshailam, A.; Dayaker, G.; Ramana, D. V.; Chevallier, F.; Roisnel, T.; Komagawa, S.; Takita, R.; Uchiyama, M.; Radha Krishna, P.; Mongin, F. RSC Adv. 2012, 2, 7030-7032.

15. Sreeshailam, A.; Dayaker, G.; Chevallier, F.; Roisnel, T.; Radha Krishna, P.; Mongin, F. Eur. J. Org. Chem. 2011, 2011, 3715-3718.

16. (a) Riant, O.; Samuel, O.; Kagan, H. B. J. Am. Chem. Soc. 1993, 115, 5835-5836; (b) Iftime, G.; Daran, J.-C.; Manoury, E.; Balavoine, G. G. A. Organometallics 1996, 15, 4808-4815; (c) Riant, O.; Samuel, O.; Flessner, T.; Taudien, S.; Kagan, H. B. J. Org. Chem. 1997, 62, 67336745; (d) Neo, A. G.; Gref, A.; Riant, O. Chem. Commun. 1998, 2353-2354; (e) Iftime, G.; Daran, J.-C.; Manoury, E.; Balavoine, G. G. A. J. Organomet. Chem. 1998, 565, 115-124; (f) Balavoine, G. G. A.; Daran, J.-C.; Iftime, G.; Lacroix, P. G.; Manoury, E.; Delaire, J. A.; Maltey-Fanton, I.; Nakatani, K.; Di Bella, S. Organometallics 1999, 18, 21-29; (g) Argouarch, G.; Samuel, O.; Kagan, H. B. Eur. J. Org. Chem. 2000, 2885-2891; (h) Glass, R. S.; Stessman, N. Y. T. Tetrahedron Lett. 2000, 41, 9581-9584; (i) Mamane, V.; Gref, A.; Lefloch, F.; Riant, O. J. Organomet. Chem. 2001, 637-639, 84-88; (j) Mamane, V.; Riant, O. Tetrahedron 2001, 57, 2555-2561; (k) Chiffre, J.; Coppel, Y.; Balavoine, G. G. A.; Daran, J.-C.; Manoury, E. Organometallics 2002, 21, 4552-4555; (1) Mamane, V.; Ledoux-Rak, I.; Deveau, S.; Zyss, J.; Riant, O. Synthesis 2003, 455-467; (m) Ferber, B.; Top, S.; Welter, R.; Jaouen, G. Chem. Eur. J. 2006, 12, 2081-2086; (n) Cortes, J. G. L.; Ramon, O.; Vincendeau, S.; Serra, D.; Lamy, F.; Daran, J.-C.; Manoury, E.; Gouygou, M. Eur. J. Inorg. Chem. 2006, 5148-5157; (o) Ferber, B.; Top, S.; Vessieres, A.; Welter, R.; Jaouen, G. Organometallics 2006, 25, 5730-5739; (p) Geisler, F. M.; Helmchen, G. Synthesis 2006, 2201-2205; (q) Omedes, M.; Gomez-Sal, P.; Andries, J.; Moyano, A. Tetrahedron 2008, 64, 3953-3959; (r) Niemeyer, J.; Kehr, G.; Fröhlich, R.; Erker, G. Dalton Trans. 2009, 3716-3730; (s) Mamane, V. Tetrahedron: Asymmetry 2010, 21, 1019-1029.

17. (a) Sanders, R.; Mueller-Westerhoff, U. T. J. Organomet. Chem. 1996, 512, 219-224; (b) Witte, P.; Lal, T. K.; Waymouth, R. M. Organometallics 1999, 18, 4147-4155.

18. (a) Steffen, W.; Laskoski, M.; Collins, G.; Bunz, U. H. F. J. Organomet. Chem. 2001, 630, $132-$ 138; (b) Zhang, W.; Xie, F.; Yoshinaga, H.; Kida, T.; Nakatsuji, Y.; Ikeda, I. Tetrahedron 2006, 62, 9038-9042.

19. Rauf, A.; Parveen, H. Eur. J. Lipid Sci. Technol. 2004, 106, 97-100.

20. $\quad$ Pickett, T., E.; Roca, F., X.; Richards, C., J. J. Org. Chem. 2003, 68, 2592-2599.

21. Patti, A.; Lambusta, D.; Piattelli, M.; Nicolosi, G. Tetrahedron: Asymmetry 1998, 9, 3073-3080: $[\alpha]_{\mathrm{D}}=-24.1\left(\mathrm{CHCl}_{3}, c=0.50\right)$ for $\left(S_{\mathrm{P}}\right)$-2-iodoferrocenemethanol with ee $>98 \%$.

22. Concerning the impact of TMEDA on reactions, see for example: Fraser, R. R.; Mansour, T. S. Tetrahedron Lett. 1986, 27, 331-334.

23. Concerning the impact of $\mathrm{LiCl}$ on reactions, see for example: Hevia, E.; Mulvey, R. E. Angew. Chem., Int. Ed. 2011, 50, 6448-6450.

24. Salvi, L.; Kim, J. G.; Walsh, P. J. J. Am. Chem. Soc. 2009, 131, 12483-12493.

25. Metallinos, C.; Snieckus, V. Org. Lett. 2002, 4, 1935-1938.

26. (a) Beak, P.; Meyers, A. I. Acc. Chem. Res. 1986, 19, 356-363; (b) Beak, P.; Kerrick, S. T.; Gallagher, D. J. J. Am. Chem. Soc. 1993, 115, 10628-10636; (c) Whisler, M. C.; MacNeil, S.; Snieckus, V.; Beak, P. Angew. Chem. Int. Ed. 2004, 43, 2206-2225.

27. Lin, G.-q.; Hong, R. J. Org. Chem. 2001, 66, 2877-2880.

28. Wright, S. W.; Hageman, D. L.; McClure, L. D. J. Org. Chem. 1994, 59, 6095-6097. 
29. Krishna, P. R.; Narsingam, M. Synthesis 2007, 3627-3634.

30. Nicolaou, K. C.; Randall, J. L.; Furst, G. T. J. Am. Chem. Soc. 1985, 107, 5556-5558.

31. Dondoni, A.; Perrone, D. Org. Synth. 2000, 77, 64-77.

32. Huffman, G. W.; Lewis, B. A.; Smith, F.; Spriestersbach, D. R. J. Am. Chem. Soc. 1955, 77, 4346-4348.

33. Graves, C. R.; Zeng, B.-S.; Nguyen, S. T. J. Am. Chem. Soc. 2006, 128, 12596-12597.

34. Gopishetty, B.; Zhu, J.; Rajan, R.; Sobczak, A. J.; Wnuk, S. F.; Bell, C. E.; Pei, D. J. Am. Chem. Soc. 2009, 131, 1243-1250.

35. Helferich, B.; Burgdorf, M. Tetrahedron 1958, 3, 274-278.

36. Kedarnath, G.; Kumbhare, L. B.; Jain, V. K.; Phadnis, P. P.; Nethaji, M. Dalton Trans. 2006, 2714-2718. 